Editorial

\title{
Decolonizing Ways of Knowing: Heritage, Living Communities, and Indigenous Understandings of Place
}

\section{Rachel Breunlin}

Neighborhood Story Project, Department of Anthropology \& Sociology, University of New Orleans, New Orleans, LA 70116, USA; rsbreunl@uno.edu

Received: 5 August 2020; Accepted: 18 August 2020; Published: 16 September 2020

check for updates

\begin{abstract}
In "Decolonizing Ways of Knowing: Heritage, Living Communities, and Indigenous Understandings of Place", we build on the scholarly and artistic practice of deep memory work to present a collection of articles, films, and artwork that contribute critical genealogies from the United States, Africa, and the South Pacific. In this introduction, examples from Antoinette Jackson's work in the American South and Rachel Breunlin's work with the Neighborhood Story Project in New Orleans and Western Australia are used to build the special issue's framework around public scholarship and art. With a particular emphasis on polyvocality, visual ethnography and creative nonfiction, the introduction argues that the work of decolonizing genealogy can be supported by respecting epistemologies that are deeply connected to place. Collectively, the contributors to the special issue demonstrate that creative practices around personal and collective histories can be an important way of reconnecting ties that may have been severed during years of colonialism.
\end{abstract}

Tell me the truth. Didn't you come from the other side?

Yes. I was on the other side.

You came back because of me?

Yes.

You rememory me?

Yes, I remember you.

You never forgot me?

Your face is mine.

-Toni Morrison, Beloved (Morrison 1987)

I brought them cigarettes

drew in a first coarse breath

blinked briefly and saw them

flash of blood memory

they saw what was still them

flash of the eye at dusk

when I doubt I'm the one

to tell this tale I hear them

from that Atchafalaya earthwork 
te nakoy get up and tell it

$$
\text { 一Jeffery Darensbourg, "Impostoral” }
$$

\section{Memory Work: The Use of Multi-Media in Critical Genealogies}

If genealogy is a pathway to our collective pasts, how can we use it as a tool to support the ongoing work of decolonization? As families have been both displaced and created during periods of colonization, how do Indigenous communities hold onto their own genealogies, which are often intimately connected to place? At the same time, how do we interrogate dominant narratives of the past that erase other histories to develop a cross-cultural, ethical approach to genealogical research? When Antoinette Jackson and I envisioned "Decolonizing Ways of Knowing," we aimed to facilitate an international conversation about how living communities interact with their ancestors and confront the legacies of colonialism through deep "memory work." Deborah Bird Rose explains this method of scholarship and artistic practice in Reports from a Wild Country: Ethics of Decolonisation:

If the purpose of violence is to extinguish certain people, knowledges and perspectives, then memory continues to resist that violence. Thus the moral burden of the past in the present includes the refusal to succumb to the world of violence and amnesia ... and [works] against the comfort of monologue. (Bird Rose 2004, p. 30)

The origins of "Decolonizing Ways of Knowing" began in conversations Antoinette and I had about the importance of public scholarship in helping families and communities confront oppressive histories in their lineages. In her first book, Speaking for the Enslaved, Antoinette writes:

Many people have posed the question: Why go back to the plantation? Why bother reconstructing a negative time in American history? I understand their sentiment and skepticism ... In school I remember stifling feelings of embarrassment behind a mask of indifference when slavery was discussed. I saw no use in looking back at that period in history. (Jackson 2012, p. 14)

Feelings such as shame and embarrassment, although painful in the moment, are sign posts that something beyond the individual is going on. Raymond Williams defined the term "structures of feeling" to investigate how meanings and values in a society are "actively lived and felt" (Williams 1977, p. 132). This work has been further developed by scholars such as Sara Ahmed, who writes in The Cultural Politics of Emotion of how feelings can direct a desire for change or create paralysis (Ahmed 2004). Paying attention to them can also provide clues to recognizing when transgenerational transmission is occurring (Breunlin et al. 2001, p. 111). When feelings are connected to historical experiences there is an opportunity to intercept trauma before it is passed on (Atkinson 2002; Schwab 2010). In her scholarship, Antoinette began incorporating the stories of enslaved Africans and their descendants into public narratives to challenge caricatures of forced labor and to highlight agency, creativity, and connections to the African diaspora and other global communities (Scott 1991; Jackson 2012).

In New Orleans, the mission of the House of Dance \& Feathers, a small, grassroots museum, has had a similar goal (Breunlin and Lewis 2009; Regis et al. 2011). Located in the Lower Ninth Ward of New Orleans, the predominantly African-American neighborhood made international headlines in 2005 when the force of Hurricane Katrina's storm surge broke a levee and leveled large parts of the community. In the aftermath, the founder and director Ronald W. Lewis rebuilt the museum in his backyard as a beacon of hope for the Lower Nine. In his exhibits, he included extended visual genealogies. For instance, in one shrine-like assemblage, he focused on the community's African heritage, the Middle Passage and the plantations in south Louisiana where his family had been enslaved. In the middle of the display, he placed a stuffed doll of a Black woman dressed to work in a white family's home. See Figure 1. 


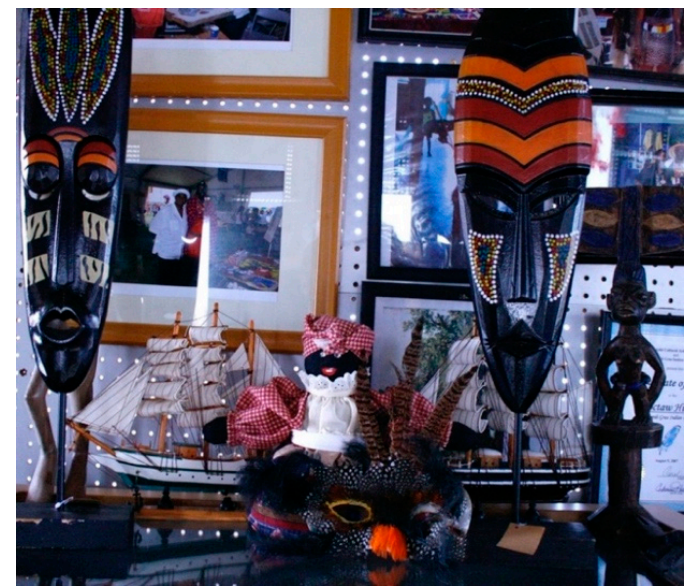

Figure 1. Ronald W. Lewis's exhibit on the transatlantic slave trade on display at his museum, the House of Dance \& Feathers in the Lower Ninth Ward of New Orleans/Bulbancha. Photograph courtesy of the Neighborhood Story Project.

Throughout the American south, white children—often raised by women who were enslaved, and later employed by their parents-played with these dolls. Into the 20th century, they continued to be collected by white families who displayed them in their homes. When I first moved to New Orleans in the mid-1990s, they were all over the tourist shops. In his poem, "secret messages," Tom Dent writes about encountering them on a walk through the French Quarter:

rain

rain drenches the city

as we move past

stuffed black mammies

chained to Royal St. praline shops.

check it out (Dent 2000, p. 201)

The dolls are mostly gone now, but Ronald refused to forget them. In his interpretation of the exhibit, he explains:

I decided to use boats and masks and figurines to show connections across places. The masks represent West African culture and the boats represent those slave ships ... And in the middle, I put an Aunt Jemima doll with its image of racism.

It's easy to just push history to the side, but I don't want to do that because it's there. To be fair, I want to identify with it all. When I talk about my mama coming off that sugarcane plantation, I'm not ashamed of that because that's where my roots are. As I was growing up, my mama always had her hair tied up in a scarf. When I see this doll, I remember that, too, and think about how my family survived those cane fields. (Breunlin and Lewis 2009, p. 13)

Ronald continued to exhibit one to reconcile two images in his mind-the woman who raised him, and a racist caricature of Black women. Calling forth W.E.B. Dubois's double consciousness (DuBois 2014), he created what anthropologist Gina Athena Ulysses calls rasanblaj-a Haitian Kreyòl word that means "an assembly, compilation, enlisting, regrouping (of ideas, things, people, spirits)" to challenge his audiences towards more honest discourse of our sense of the past (Ulysses 2015).

In the summer of 2020, the massive Black Lives Matter protests around the United States over the murder of an African-American man, George Floyd, by a white police officer in Minneapolis, Minnesota, can also be seen as a form of rasanblaj. Read as a collective text, the signs people have 
carried document genealogies of racism and resistance in the United States. On June 5, I asked my 11-year-old son, Max, what kind of sign he wanted to contribute to a protest that was planned at the central plaza of New Orleans-just a short walk from the Mississippi River. He said he would draw the Black Power symbol of a fist raised in the air to show support for Black strength and leadership. At the protest, he stood next to a masked man in a baseball cap who held up a sign with a picture of Trayvon Martin (1995-2012), a Black high school student who was shot and killed by the neighborhood watch captain of his father's gated townhome community in Florida after he called 911 to report that the young man looked suspicious walking in the rain in a "dark hoodie" (Coates 2013). Nearby, Niya Zulu, one of my students who recently graduated from the Department of Anthropology at the University of New Orleans, held a sign that covered most of her body: "Police Brutality Equals Lynching." See Figure 2.
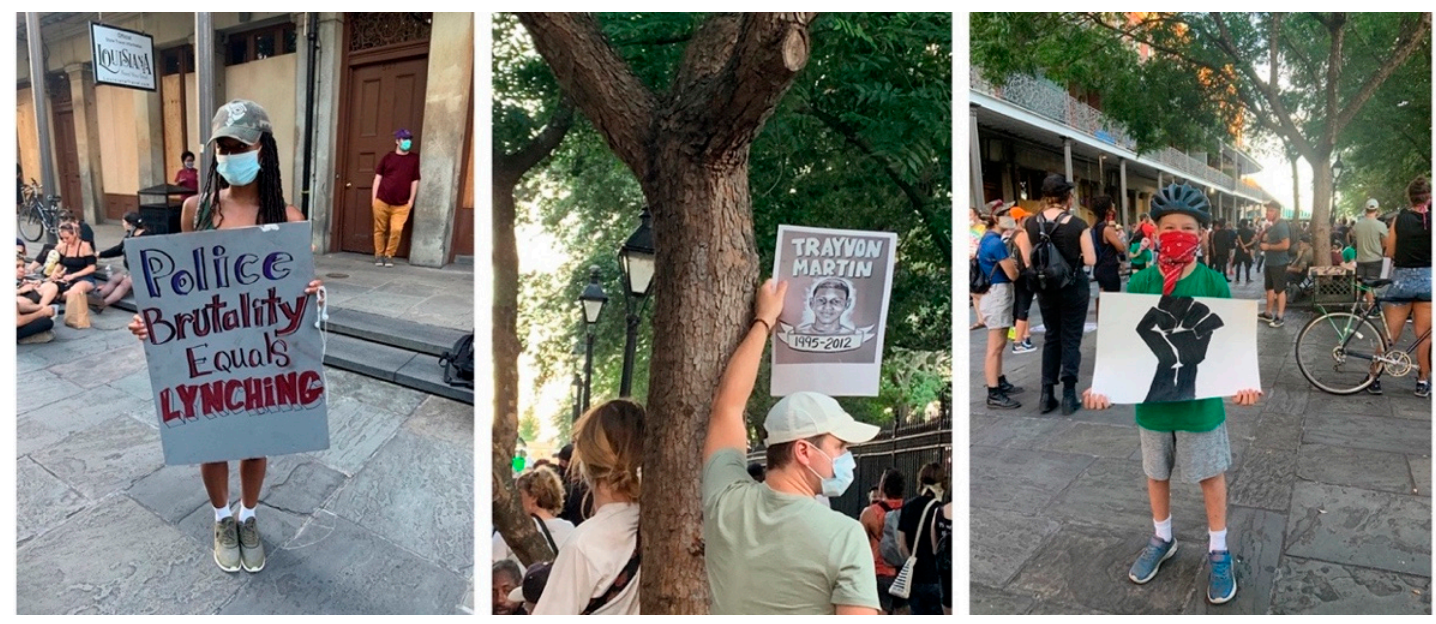

Figure 2. Signs at the Black Lives Matter protest on 5 June 2020 in the French Quarter of New Orleans. Right to left, Niya Zulu's sign "Police Brutality Equals Lynching"; a poster linking deaths due to police brutality with other attacks on Black lives such as the shooting of 17-year-old Trayvon Martin; the author's son, Max Etheridge, with a Black power sign that he painted. Photographs by Rachel Breunlin.

I asked Niya if I could take her picture with the sign because we were standing on the site of many government-sanctioned lynching. In 1784, during a time when the site was known as Plaza de Armas (Place d'Armes), the Spanish colonial government, the Cabildo, publicly executed Juan San Malo and other maroons who had escaped slavery (Hall 1992). But the murder of the maroons did not stop the resistance. In 1811, participants in the largest slave revolt in the history of the United States marched from the German Coast down the river's levee towards New Orleans. When apprehended, more than 100 people were beheaded, and their heads were placed on poles, "dangling their dismembered corpses from the gates of New Orleans. 'Their Heads, which decorate our Levee, all the way up the coast... look like crows sitting on long poles,' wrote one traveler" (Rasmussen 2017).

In the 1830s, the city of New Orleans offered a reward for a maroon named Squire, who became more widely known as Bras Coupé (Severed Arm), as legends developed around how he had avoided capture for 18 months. Wanted dead or alive, in 1837, Bras Coupé was killed by an associate who then brought his body to the Cabildo. As a warning to others, Mayor Denis Prieur hung his corpse in Place d'Armes for days. Literary historian Bryan Wagner quotes a contemporary account of the scene:

No Mardi Gras procession, no special pageant that I know ... ever attracted such surging crowds as were witnessed under that broiling, solstitial sun. Men, women, and children; whites and blacks, freedmen and slaves; professional men and laborers in their working blouses all seemed to have gathered there to satisfy their curiosity. (Castellanos quoted in Wagner 2019, p. 11) 
In the years since these violent acts against freedom, stories of San Malo, the participants of the slave revolt, and the legacy of Bras Coupé have been part of counter-memories that focus on the lives, rather than deaths, of the early revolutionaries (Barnes and Breunlin 2019; Wagner 2019). In protest, art, film, songs, and altars, the dead are still with us. See Figures 3 and 4.
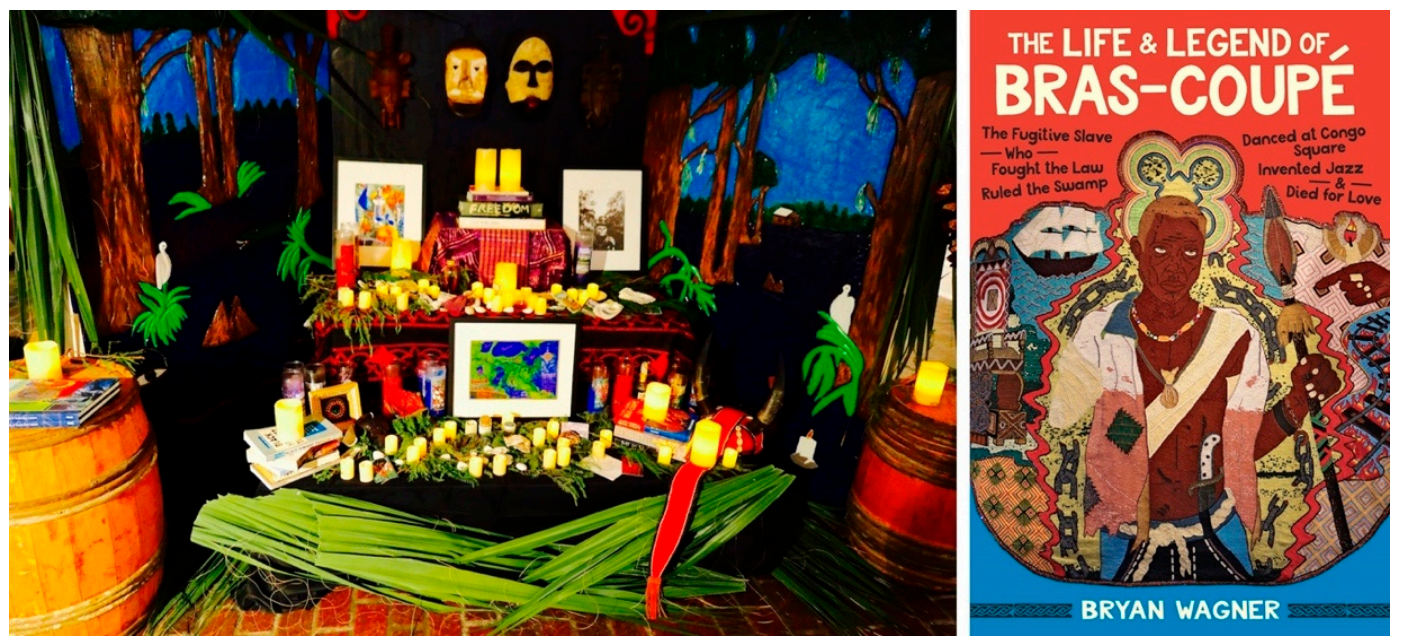

Figure 3. (Left): An altar dedicated to the memory of Juan San Malo, a maroon leader in south Louisiana in the 1780s, and other freedom seekers around the world, on display at the Louisiana State Museum's Arsenal \#1 at the Cabildo on Jackson Square as part of the Neighborhood Story Project's exhibit Le Kèr Creole (The Creole Heart): Runaway Slaves, Music, and Memory in Louisiana in 2019. Photograph by Bruce Sunpie Barnes. (Right): On the Neighborhood Story Project's altar is a copy of Bryan Wagner's book dedicated to the history and legend of Bras-Coupé, an enslaved man who escaped bondage in the 1830s (Wagner 2019). The artwork on the cover is a beaded portrait of Bras-Coupé by Demond Melancon, Big Chief of the Young Seminole Hunters. Photograph courtesy of Bryan Wagner.

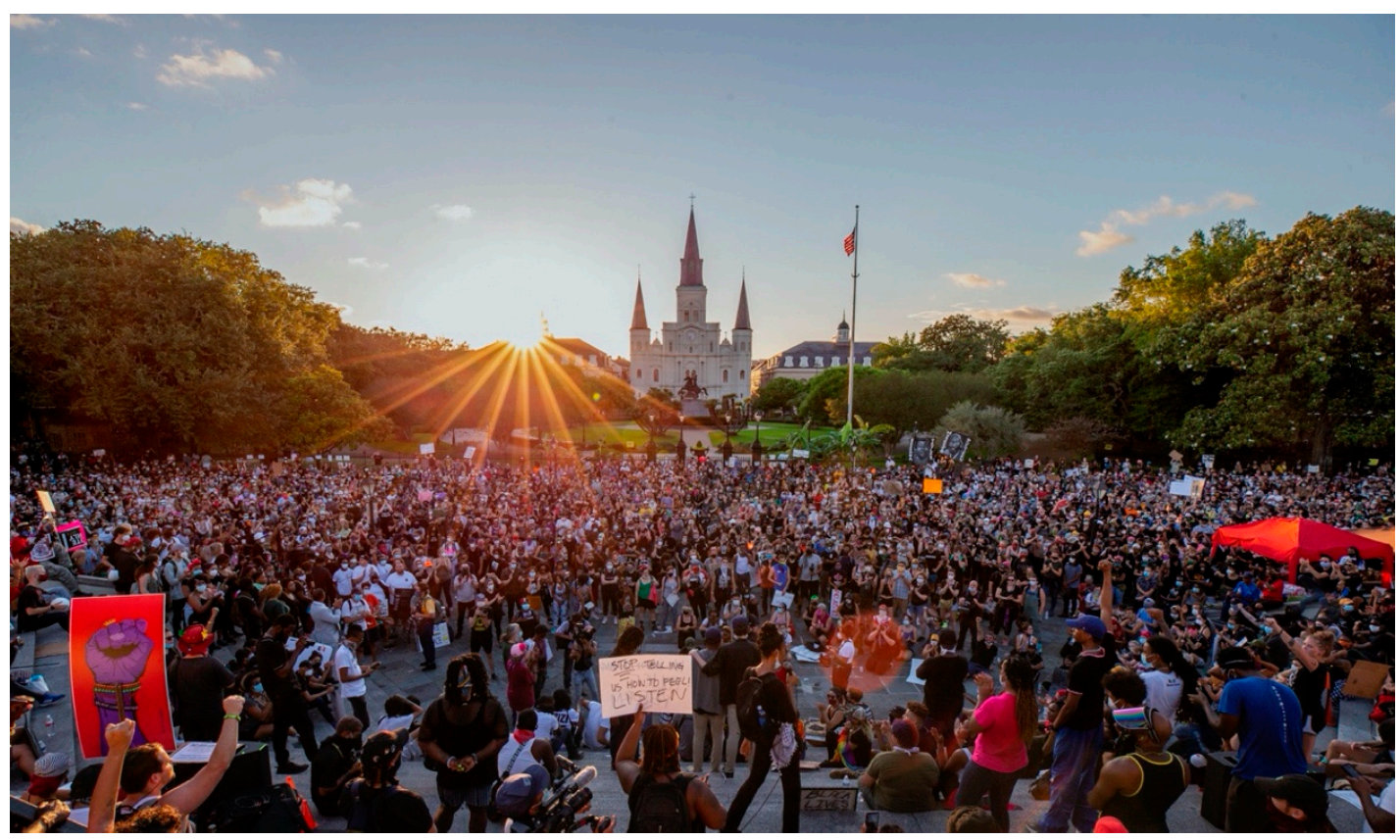

Figure 4. Black Lives Matter protest at Jackson Square in New Orleans on 5 June 2020. Photograph by David Grunfeld, courtesy of NOLA.com, The Times Picayune | The New Orleans Advocate.

In 1851, the city of New Orleans renamed Place d'Armes "Jackson Square" in honor of Andrew Jackson's leadership during the Battle of New Orleans. Five years later, 60,000 people attended the 
unveiling of an equestrian sculpture of the former president rising from the middle of the square (Wegmann et al. 2020). On the evening of the Black Lives Matter protest in 2020, thousands gathered again, but no one was allowed to enter the gated park. Protestors surrounded the edges, and informal history lessons circulated: Jackson was a slave owner who supported genocidal policies against Indigenous nations in the United States. The river, held above us by man-made levees, was the dividing line of the Indian Removal Act of 1830, which forced Indigenous Nations to relocate to "Indian Country" (Saunt 2020). See Figure 5.

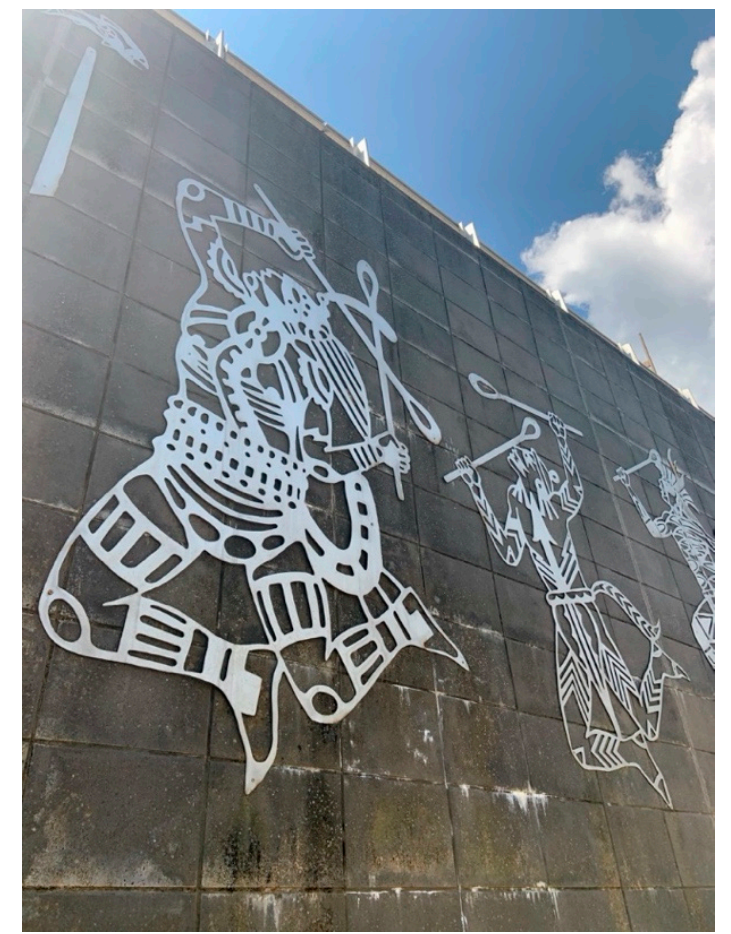

Figure 5. Cherokee stickball players on the edge of the Tennessee River in Chattanooga, Tennessee, are part of public art project "Passage," by Team Gadugi ("Working Together" in Cherokee). The site, formerly known as Ross's Landing, was the beginning of the Trail of Tears. After the federal government's Indian Removal Act was passed in 1830 during Andrew Jackson's presidency, thousands of Cherokee were forced to walk to Indian Country in what is now Oklahoma.

Around the world, diverse tribal nations have experienced similar displacement, which has been reinforced through an erasure of Indigenous understandings of genealogy and their ties to land. In his ethnography, At Home in the World, Michael Jackson writes:

Definition is itself at the roots of racism: the way we reduce the world to a word, and gag the mouths of others with our labels. One man put it very succinctly: "Amongst ourselves we are people, whites turn us into Aborigines." (Jackson 1995, p. 14)

After years of critiquing the way racial categories have been used to divide and conquer, anthropologists have also become mindful of other traps of language, including "the most problematic connotations of 'culture': homogeneity, coherence, and timelessness" (Abu Lughod 1993, p. 14). In this special issue, we recognize that the word "Indigenous" has been reclaimed by many First Nations, while also acknowledging that the term developed out of early anthropological thought in the early 20th century when the discipline assumed, "cultures were bounded and isolated from each other and that they have a purity and authenticity that can be identified and catalogued" (Regis 2019, p. 152). Memory work breaks these assumptions down (Harrison 1991; Davis and Craven 2016). 
On the 300-year anniversary of France's founding of New Orleans in 1718, Jeffery Darensbourg, a historian and tribal councilman of the Atkapa-Ishak in Louisiana, spearheaded Bulbancha Is Still A Place, a zine he produced with an Indigenous collective in Louisiana. See Figure 6.

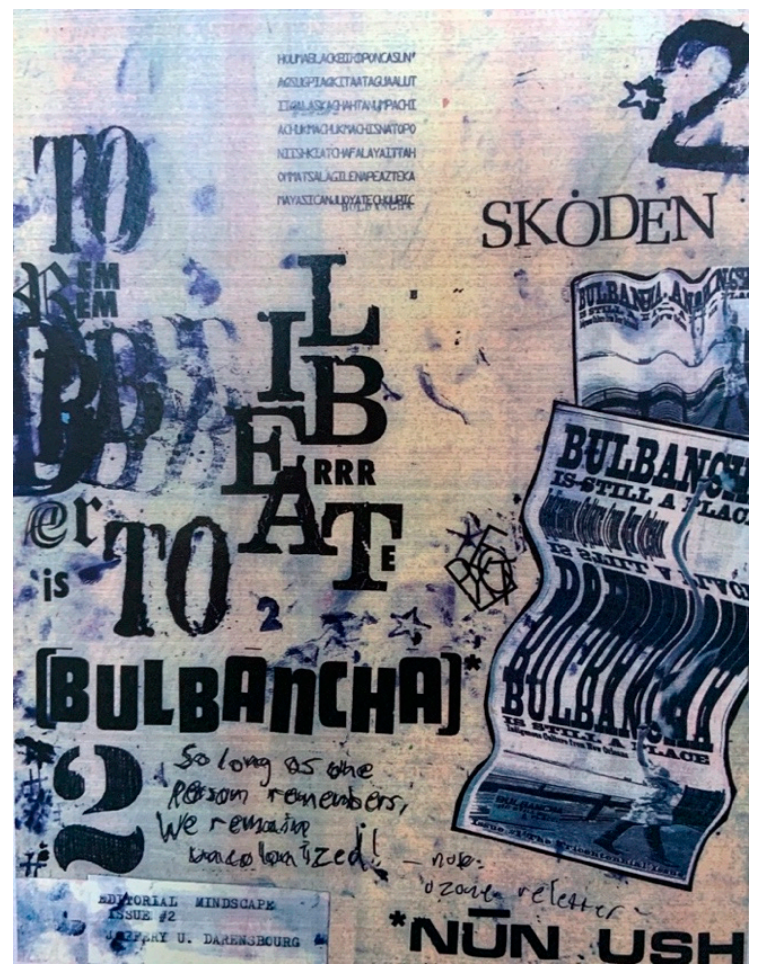

Figure 6. Bulbancha \#2, a visual poem by Jeffery Darensbourg, a tribal representative of the Atkapa-Ishak Nation in Louisiana and Contributing Editor-Who's-Not-A-Chief of the zine Bulbancha Is Still a Place, the first publication of writing and art published by Indigenous Louisianans which he produces with his editorial partner, Ozone504. The poem first appeared in "VERBIVOVISUAL: Visual and Multimedia Poetry" at Barrister's Gallery as part of the New Orleans Poetry Festival in 2019. Image courtesy of the artist.

In the introduction to the zine, Jeffery explains the power of decolonizing the name of the city:

Bulbancha, "the place of many languages," or "the place of many tongues," is the original name for this area ... Bulbancha is much older than New Orleans. It is also closer to the heart of the matter. Before the first Europeans came here, it was a place where people from around 40 distinct Native groups crisscrossed, traded, followed game and fish, moved to rising and falling waters and interacted with one another. It was a place of diversity, and changes, where people came and went in search of what they needed, including the Chitimacha, Houma, Chawasha, Washa, Acolapissa, Tunica-Biloxi, Baogoula, Natchez, Taensa, Atakapa-Ishak, and other groups as well. That was Bulbancha then; this is Bulbancha now: a complex, multi-ethnic, multicultural place. (Darensbourg 2018, pp. 2-3)

Inspired by the cosmopolitan ethic of Bulbancha, we have invited scholars and artists from Africa, the South Pacific, and the United States to develop a cross-cultural dialogue about decolonizing genealogy. Following Saidiya Hartman's "history of the present," this project works:

to illuminate the intimacy of our experience with the lives of the dead, to write our now as it is interrupted by this past, and to imagine a free state ... as the anticipated future of this writing. (Hartman 2008, p. 4)

Here, we want to highlight our contributors who have combined genealogical research with creative nonfiction and autoethnography, as well as artwork, film, and a critical examination of archives, 
to contribute dynamic experiences with family, ancestors, and land. Through the open-source format of this journal, we hope to redistribute critical genealogies back to the communities represented in the articles in ways that contribute to dialogues already at play, and to provide new opportunities to look at personal and collective lineages.

\section{Honoring Place Through Home Languages}

After hundreds of years of British colonization, English is now the most spoken language in the world (Mydans 2007). Vast anglophone libraries and online databases have been developed and used to shape educational institutions. In many parts of the world, scholars and students who speak other languages predominantly write in English. While this special issue contributes to the anglophone archive, we encouraged our contributors to share epistemologies embedded in their home and/or community languages. When we take the time to pay attention to the translations, we practice a form of decolonizaiton. For instance, in the mid-twentieth century, W.E.H. Stanner wrote to Anglo audiences about what can be learned from Indigenous languages in Australia:

No English words are good enough to give a sense of the links between an Aboriginal group and its homeland. Our word "home," warm and suggestive though it may be, does not match the Aboriginal word that may mean "camp," "hearth," "country," "everlasting home," "totem place," "life source," "spirit centre," and much else all in one. Our word "land" is too spare and meagre. We can now scarcely use it except with economic overtones unless we happen to be poets. The Aboriginal would speak of "earth" and use the word in a richly symbolic way to mean his shoulder" or his "side". (Stanner 1979, p. 230)

Similarly, in Kayang and Me, Kim Scott meditates on how learning words in Noongar, an Indigenous language from Western Australia, helps connect to local landscapes. He shares the work of lexical cartographer Jay Arthur, who has asked Anglo-Australians to consider the limitations of English words used to describe Australian ecologies. For instance, "[t]he word 'drought' in a country where rainfall is naturally irregular ... encourages us to be disappointed, to feel cheated, to see the land as hostile (Scott and Brown 2005, p. 219). Scott provides another example in the word "river," which:

only approximates what in Australia is known as a river Along the south coast a "river" is typically a tenuously linked sequence of ponds barred by a sandy beach from reaching the sea ... Kayang Hazel tells me the Noongar word for river is bily. It is also the word for navel.

(Scott and Brown 2005, p. 220)

The work of holding onto endangered languages can lead different ways of knowing. Robin Well Kimmerer writes of how she learned a "grammar of animacy" by studying her family's language. In English, verbs make up 30\% of the vocabulary, but in Potawatomi, they account for $70 \%$. She explains what happen when nouns are transformed into action words:

When bay is a noun, it is defined by humans, trapped between its shores and contained by the word. But the verb wiiwegamaa - to be a bay-releases the water from bondage and lets it live. "To be a bay" holds the wonder that, fro-this moment, the living water has decided to shelter itself between these shores, conversing with cedar roots and flocks of baby mergansers. (Kimmerer 2013, p. 55)

Just as we would recoil in English from someone who refers to a person as "it," so would a fluent Potawatomi speaker if they heard someone objectifying plants or animals (Kimmerer 2013, p. 56).

In 2008, I had an opportunity to work with a group of multilingual women from the Kimberley region of Western Australia who traced their genealogies through Saltwater, Freshwater, and Desert countries. In the tropical savannah of the Kimberley, the seasons consist of "the dry" and "the wet," accompanied, on the coast of the Indian Ocean, by one of the largest tidal ranges in the world. Inland, the region is shaped by one of Australia's last wild rivers, the Fitzroy, known as Mardoowarra in the 
Nykina language. Scholar and traditional custodian Dr. Anne Poelina, a gifted cultural translator, explains the spiritual significance of the river for her tribe:

[T] he river was formed in the beginning of time by Nyikina ancestor, Woonyoomboo. Woonyoomboo is the human face of the Mardoowarra and in partnership with Yoongoorrookoo, the sacred ancestral spiritual living being, created the river valley tracks. Woonyoomboo was an explorer, map maker, and scientist who named the places, animals, birds, fish, plants, and living water systems. (Poelina 2018)

The Fitzroy's wetlands and tributaries stretch to the edge of the Great Sandy Desert, where many Walmjarri, Jaru, and Mangala people lived on their traditional land until the 20th century and are still fluent in their languages.

The collaborative ethnography I came to work on, Singing Out: Aboriginal Ladies' Stories from the Northwest Kimberley, was hosted by the Jalaris Aboriginal Corporation, which is run by Biddy Morris and her husband, Brett (Breunlin and Haviland 2008; Haviland 2014, 2017). Biddy's family is from Bardi country on the coast, but she was born during the years after the Australian government had created regional Aboriginal Reserves in an attempt at forced settlement. People who had followed seasonal migrations on their traditional country were forced to live in town. In 1944, Biddy's mother gave birth to her in Derby in a repurposed water tank where she made her home. Their neighbors looked into the door that had been cut out of the tank, found them inside, and took Biddy to the Native Hospital run by the Western Australian government. From the first days of her birth, she has been traveling between cultures, and recognizes the importance of honoring the skill sets needed to code switch between them. As Walter Benjamin writes, at its best, translation "does not cover the original, does not block its light" but shines back upon the original "more fully" (Benjamin 1969, p. 79).

For the women involved in Singing Out, the town of Derby is a cultural crossroad between many different language groups. Biddy's aunty, Bessie Ejai, tells the history of the settlement:

Nykinia and Warrwa people belong to here. This is their country. They used to call it, in the olden days, Yarday. Now they call it Badulah. Them white man named it Derby. (Breunlin and Haviland 2008, p. 128)

Slowing down to discover what these names are referencing, we learn that "Yarday" means "North" in Warrwa, a language similar to Nyikina that is now extinct-one of more than 100 Aboriginal languages which have been lost since British colonization (McGregor 1994; Poelina 2013). Yarday is a "cardinal direction" in Warrwa, one of four quadrants that form a fixed frame of reference for understanding where something or one is located (McGregor 2006, p. 149). In this case, Yarday helps us understand that the town of Derby was founded in the northern territory of Warrwa country in 1883. Named after Edward Henry Stanley, the fifth earl of Derby and the secretary of state for the British colonies, Britain established it to support the growing pastoral industry, which was simultaneously displacing many Aboriginal people from their land throughout the region. Under the arc of this history, the last name Bessie references, "Budalah," can be seen as an act of reclamation within these colonized boundaries. Overseen by the Winun Ngari Aboriginal Corporation, it is a small community within Derby that was developed to support Aboriginal housing needs.

There are many stories of birth in this home place. In 1930, Bessie was born under a boab tree in Derby. Amongst Nyikina people, boabs are considered special places that are called ray/rai (Cross 2019). Anne Poelina explains that rai is used for a place that, "gave rise to the formation of a person's spirit." It connects them to the life force, and "grounds their cultural birthright to that location" (Poelina 2016). See Figure 7. 


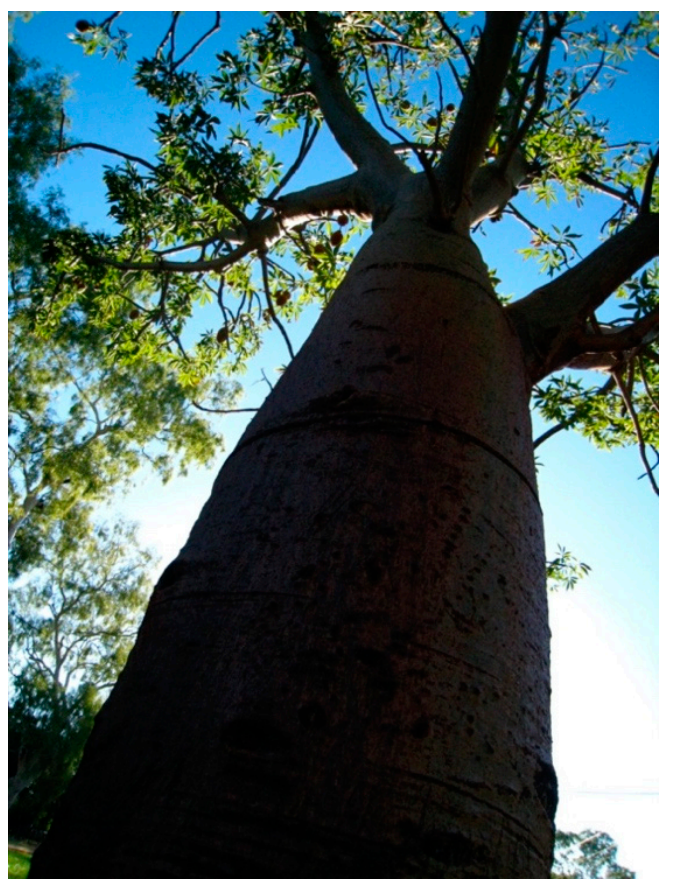

Figure 7. A boab tree (Adansonia gregorri) in Derby, Western Australia. Closely related to the African boabab, they are found in the Kimberly region of Western Australia and small parts of the Northern Territory. The pith of the tree is high in Vitamin C, the seeds can be roasted, and water is stored in its trunk, which was important for families during the dry season. According to Nykina elder Annie Milgin, boabs are home to spirits that come up from the roots and see out from the flowers (Cross 2019). Photograph by Rachel Breunlin.

Despite Bessie's family's strong connection to Nyikina country, when she was a young girl, the Australian government's Welfare department sent her hundreds of miles away to the Sunday Island Mission. Growing up on the island, she learned to speak Bardi with her friends, and English in school. She is now one of the last fluent speakers of her adopted language, and has spent many years trying to preserve it (One Arm Point Remote Community School 2010). She explains:

I only know talking Bardi ... My mum used to talk to us in Nyikina ... I understand the old people talking to me, but I answer them in English. (Breunlin and Haviland 2008, p. 128)

In many ways, Aboriginal English became a trade language-a liminal space between Indigenous communities that were often displaced after British colonization. For instance, Carlene Wise's mother (Walmajarri) and father (Mangala) came from Desert Country. She explains that, "Whitefella mixed Mangala up with Nyikina and moved them to a big block out from the Fitzroy River called Looma" (Breunlin and Haviland 2008, p. 70). Amongst the other languages, she learned her mother's tongue from the Great Sandy Desert:

I grew up speaking Walmajarri. It's an easy one-Nyikina and Mangala are too hard. When they talk those languages, I tell them to speak English. (Breunlin and Haviland 2008, p. 70)

Paul Stoller has written about anthropologists being "sojourners of the 'the between,"' yet Biddy, Bessie, and Carlene are also sojourners; members of transnational families who have experienced both the insight and disconnections that come from moving between places and languages (Stoller 2009, p. 4). Carlene's family still returns to the Great Sandy Desert for funerals, but she does not feel as comfortable there as she does by the Fitzroy. "After a few days, we wanted to go back to our river" (Breunlin and Haviland 2008, p. 71). See Figure 8. 


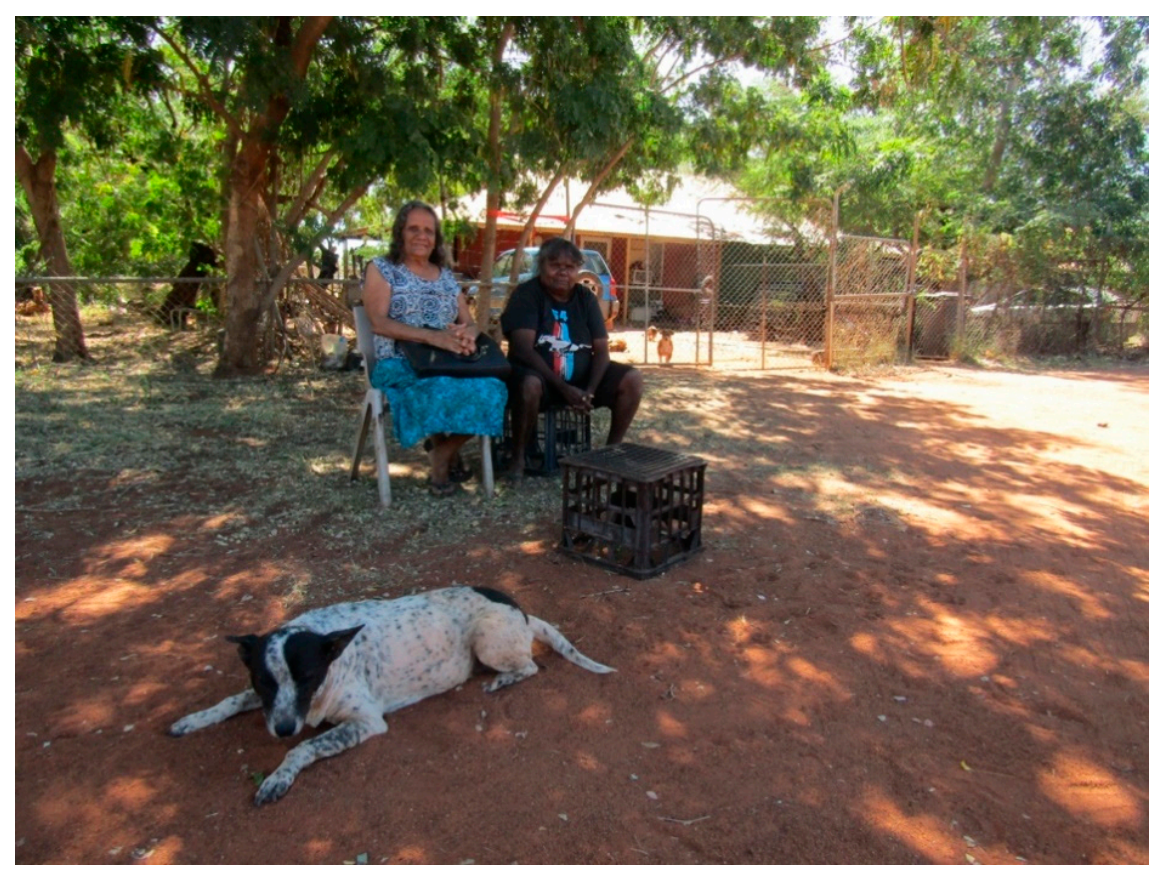

Figure 8. Biddy Morris and Carlene Wise, co-authors of Singing Out: Aboriginal Women's Stories from the Northwest Kimberley, in Western Australia, with Miwa in the foreground. Photograph by James Pillsbury.

\section{Embodied Memory: Returning to the Dead}

In many parts of the world, the dead are invited into living communities to do memory work and participate in the day-to-day experiences of their families. Embodied experiences of genealogy - whether calling on spirits through possession, passing on a craft, or unspoken habitus-connect family members to their ancestors. One of our special issue contributors, Abiodun Akande, grew up in Ibadan, Nigeria, attended university in Ile-Ife-considered to be the ancestral and spiritual heartland of the Yòrùbá-before moving to Ago'dOyo (Oyo City) for his first teaching position in art. He recalls:

I have never seen anything like it before. I have been to so many Yoruba towns, but there appears to be none that is comparable to Oyo. It is like every household has a babaláwo (Ifa diviner) or two, as well as other traditional religion worshippers such as Sango, Obatala, and Osanyin as members. Even some young boys between the ages of 18 and 20 years, who were my students, were practicing babaláwos or ardent worshippers of one form of Yoruba traditional religion or another.

Amongst the òrisa (dieties) that are worshipped is Egúngún-Oya, the mother of the collective spirits of the ancestors. In Yorùbá, the word egúngún:

is a compound word formed by the combination of morphemes/e + gún + gún/, literally "that which facilitates or brings about stability, unity, peace, and joy" among others. (Fámúlè 2018)

"O-ya" is also a compound word which translates as "she tore." Revered by market women, Egúngún-Oya oversees the cemetery, and is called upon for transformation. Örisa of wind and lightning, she harnesses the destructive power of tornadoes that form along the Guinea Coast when winds from the Atlantic Ocean, the Saharan desert, and eastern dry savannah converge to bring about change- the same winds that build in the ocean to make land fall as hurricanes in the Caribbean and southern United States. For this special issue, Abiodun shares his research on two egúngún from Òyó. See Figure 9. 


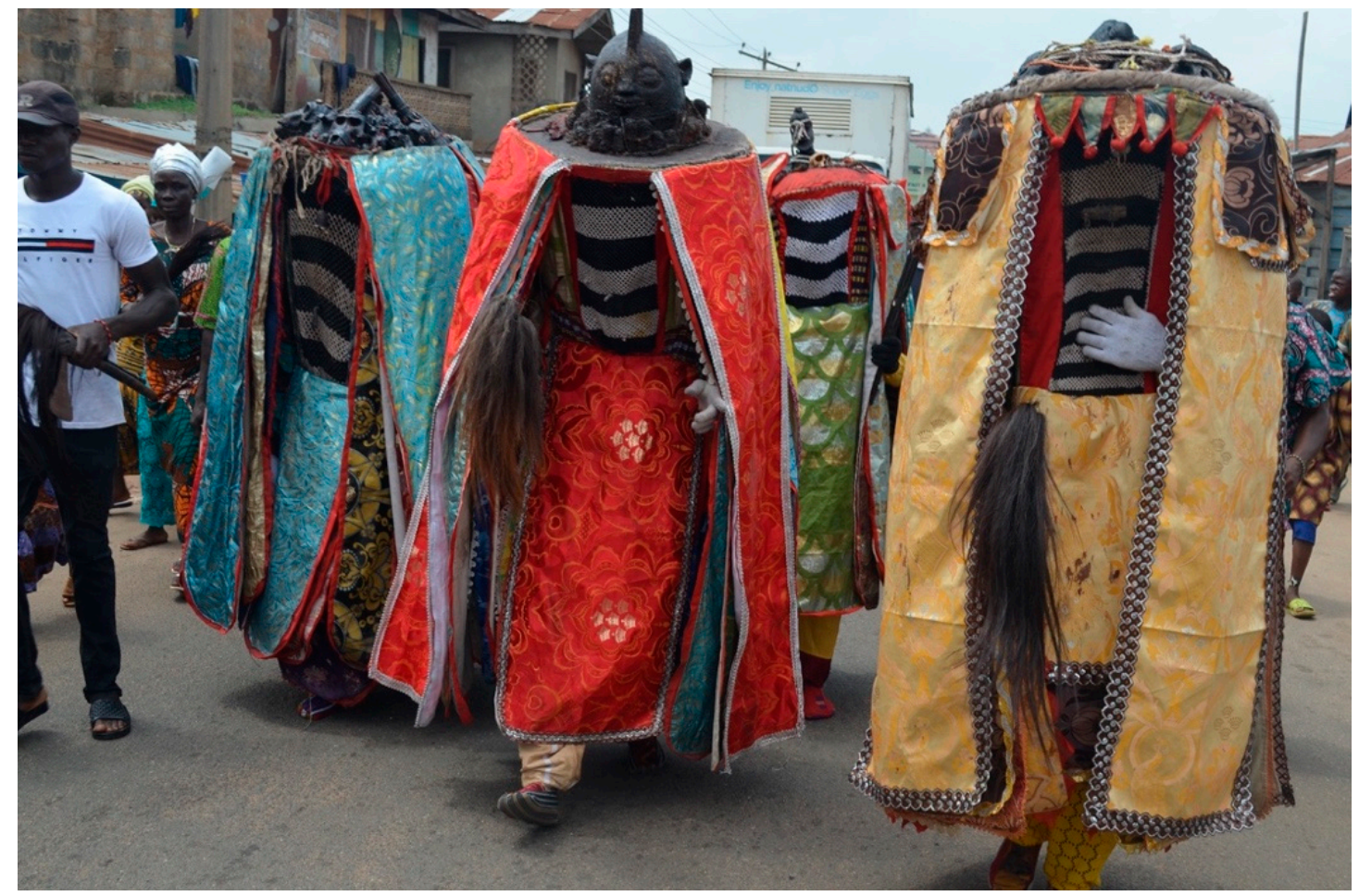

Figure 9. Egúngún masquerade in the Nigerian city of Oyo. Photograph by Akande Abiodun.

From in-depth interviews with a wide network of people who take care of the egúngún, Abiodun shares the multiple ways that the "robust Yorùbá belief in life after death" manifests itself in the spirits of ancestors in the city.

In West Africa, the active exchange between the living and the dead is often interpreted through divination. As one Vodou priest in Togo explained, "We Ewe are not like the Christians, who are created by their gods. We Ewe create our gods and create only the gods we want to possess us, not any others" (Rosenthal 1998, p. 45). Many Ewe shrines honor the spirits of enslaved people who were kidnapped in northern Ghana and were either kept as slaves or sold to in the trans-Atlantic slave trade. A white American ethnographer was informed by an Afa diviner that she should reckon with her family's past as well:

Why should you not pay your debts to the slave spirits the way we Ewe do? You would be better off for it their spirits are powerful; they can help, heal, and protect you when you need them, if you honor them fully. (Rosenthal 1998, p. 153)

In the United States, the descendants of slave owners are often reluctant, or outright hostile, at the suggestion that they should pay debts to those they enslaved. The memories are often preserved outside of dominant narratives, and through family and community practices. See Figure 10. 


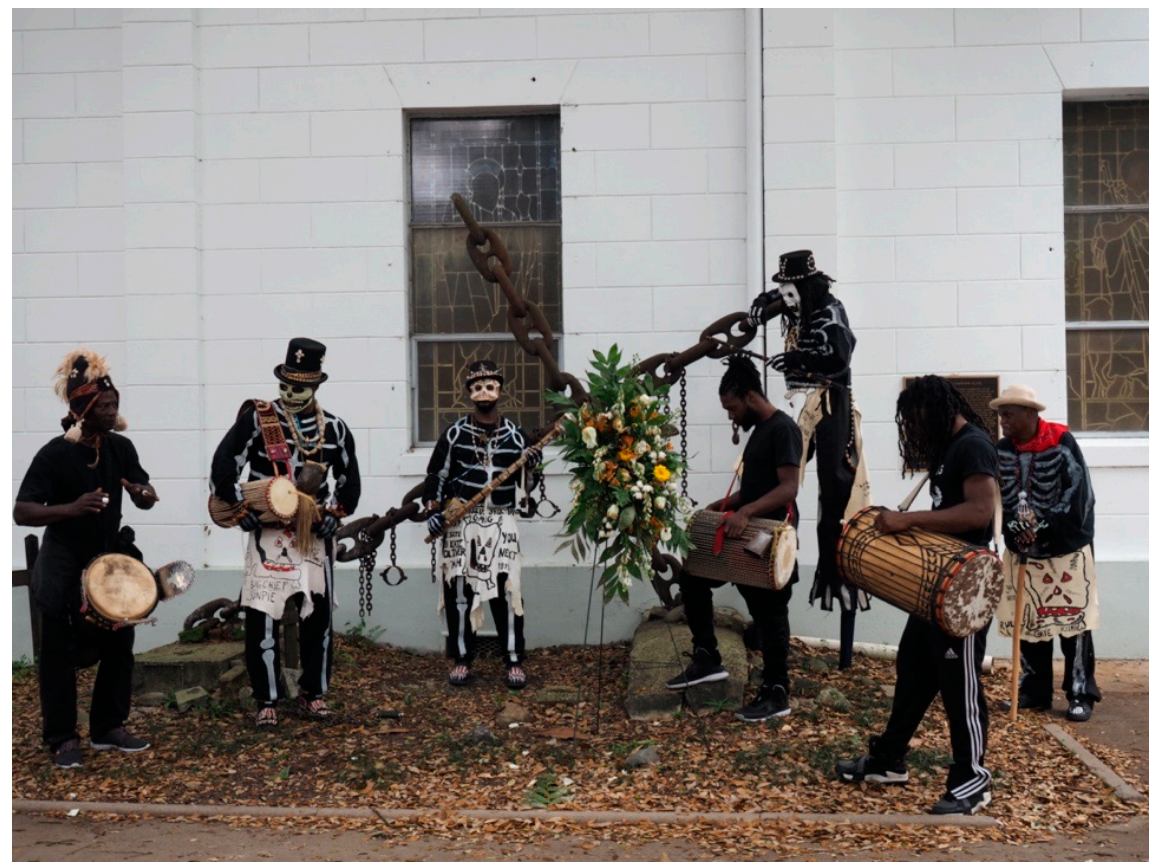

Figure 10. Tomb of the Unknown Slave at St. Augustine Catholic Church in the Tremé neighborhood of New Orleans. Every Mardi Gras, the Northside Skull and Bone Gang, an African-American men's carnival organization led by Bruce Sunpie Barnes, visits the memorial to pay homage to their ancestors. From left: Seguenon Kone, Bruce Sunpie Barnes, Bruce Brown, Bakari Blackman, Solomon Israel, Zohar Israel, and Ronald W. Lewis. Photograph by Jeffrey David Ehrenreich, courtesy of the Neighborhood Story Project.

In the Gullah-Geechee community around Boone Hall plantation in Mt. Pleasant, South Carolina, Antoinette documented how Gullah families stayed connected to their ancestors through the art form of sweetgrass basket sewing (Jackson 2012). More than 300 years ago, slave traders deliberately kidnapped West Africans from rice growing regions for their knowledge of rice production, which included the intricate skills in sewing baskets (Fields 2008). African labor and ingenuity became central to the economy, craftmanship, and foodways that developed in the South. Their skill set was, in fact, the basis for the region's dominance in the exportation of rice from the 17th to the 19th centuries (Carney 2001; Jackson 2011; Jackson 2012). See Figure 11.
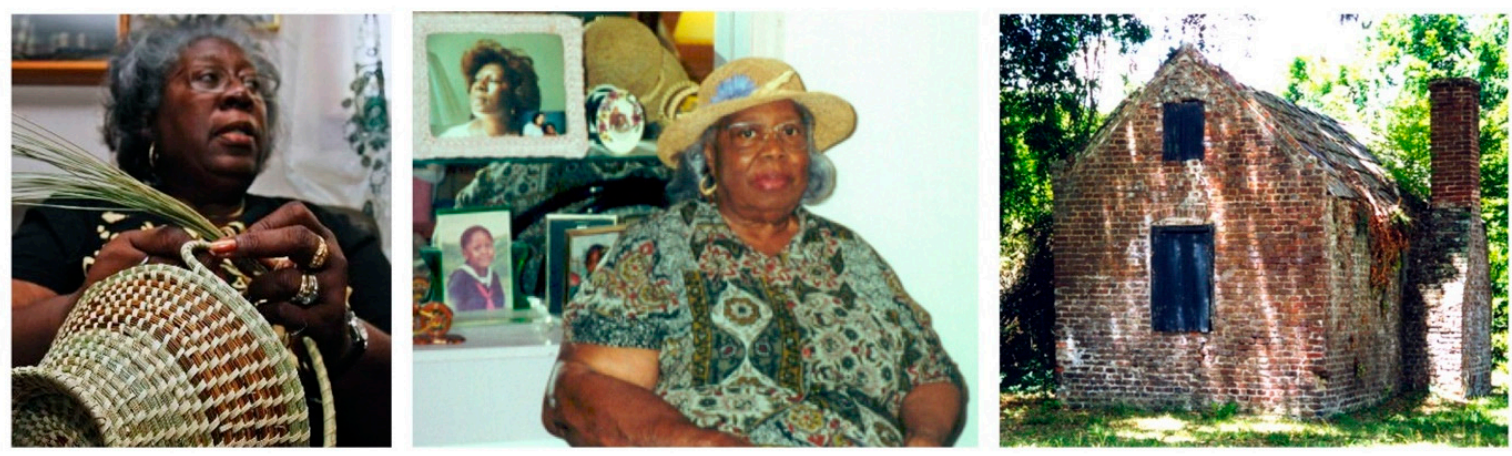

Figure 11. Boone Hill legacy collage. (Left): Jeanette Lee, whose family descended from the Boone Hall plantation, sewing a sweetgrass basket. Photograph courtesy of Kyle Stock. (Middle): Jeanette's mother, Ms. Mattie Gaillard, at her home in Mt. Pleasant, South Carolina. (Right): The former slave cabin where Ms. Mattie grew up in on Boone Hill plantation in Charleston County, South Carolina. Photographs by Antoinette Jackson. 
In Denise Frazier's article in our special issue, "The Nickel: A History of African-Descended People in Houston, Texas," she writes of how she discovered connections between her family and the broader African diaspora in Bahia, Brazil. At a conference, an Afro-Brazilian woman asked Denise whether her grandparents ate with their hands:

Her question still haunts me to this day. It was as if she had time-travelled and caught the quizzical look on my ten-year old face as I observed how my grandparents ate. They used utensils, but there was also a mixing of various foods and a use of the thumbs with the pointer finger and middle finger to scoop mixed flavors of cornbread with chicken and greens into a delightful bite in a way that may be similar to how West Africans use fufu. I asked my mother why my grandparents did this and was dismissed. It was as if my observation was shameful or not polite enough to prompt further inquiry. (Frazier 2020, p. 20)

Once again, emotion is the first sign that a larger story needs to be told. When the feeling runs against dominant discourse, it may take time to begin to incorporate new ways of knowing. Denise reflects:

As I have gotten older, I have delighted in picking up pieces of arugula with my fingers at formal or casual dinners in public or in my own home. I frequently mix my foods, putting salad on top of beans and rice and mixing them all together. Doing so honors the cultural memory that I have retained from my grandparents and celebrates the way they enjoyed eating-with utensils, as well as with their hands. (Frazier 2020, p. 20)

\section{Carving out Space: Genealogies of the Land}

In this special issue, many of our contributors emphasize the importance of connecting kinship to place. In many Indigenous cultures, it is important to trace descent beyond human connections to the natural and built environment. As Yirga Woldeyes quotes in Ge'ez in his article, "Lalibela: Spiritual Genealogies Beyond Epistemic Violence in Ethiopia": “बهh\} (Place blesses humans and humans bless place). Yirga elaborates on the importance of the ancient rock-hewn churches of Lalibela, the town where he was raised, in the Ethiopian Orthodox Tewahido Church:

Like other indigenous perspectives, rather than being conceived as a tabula rasa, waiting to be authored or acted upon by human beings, the traditional beliefs of Ethiopians understand place to have agency that can impose demands on human beings ... Like other African philosophical traditions ... which view life as a sacred connection among the human, the non-human and the spirit world, Lalibela's churches are places embodied with spiritual meaning and identity. (Woldeyes 2019, p. 4)

The Tewahido Church traces its roots genealogically back to King Solomon and is considered the indigenous religion of most Ethiopians. See Figure 12. 


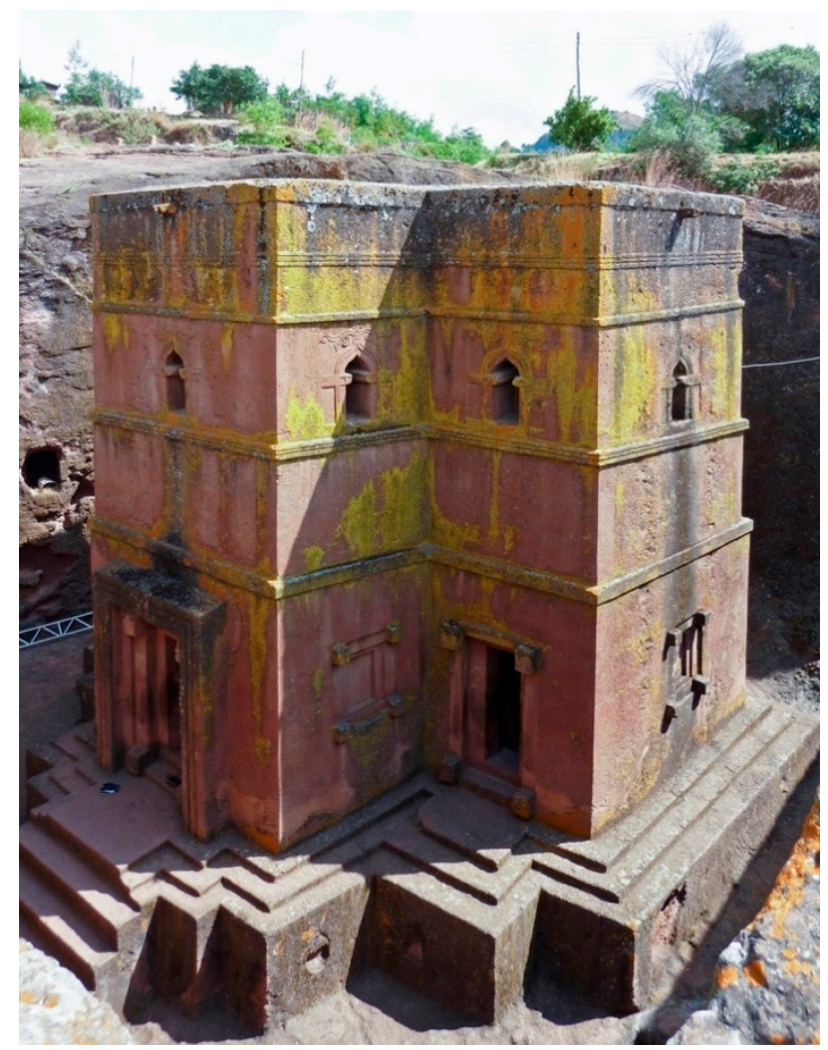

Figure 12. Bete Giyorgis (St. George), one of the rock-hewn churches of Lalibela, Ethiopia, is home to a bee colony said to have begun in $900 \mathrm{CE}$.

Yirga's first language is Amharic. In public school, he learned English, and in the rock-hewn churches, he learned to understand and read in Ge'ez-an Afroasiatic language that was originally spoken in the region 10,000 years ago (Kebede 2003; Woldeyes 2020). He learned this ancient language through the grassroot educational systems of Lalibela:

attending Sunday school and from listening to the stories of the hermits, monks, nuns, priests and spiritual scholars who lived in communion with the church and our community ... Other times, my friends and I gathered in the compound of Bete Medhanialem and in the caves of Amanuel and Bete Mariam churches to study scripture with the monk-scholar Aba Zekarias. He was referred to as Arat Ayina, Four Eyed-someone with the ability to see the past as well as the future. Arat Ayina knew infinite stories, verses and fables. He read from the ancient books written in Ge'ez, and used Amharic to educate us in the 81 books of the Ethiopian (Woldeyes 2019, p. 3)

Amongst Tewahido believers, the important sacred text is $7 \mathrm{f} \lambda \lambda \lambda \lambda \lambda$, The Acts of Lalibela, which was written in Ge'ez, and recently translated into Amharic. For his article, Yirga translated parts of The Acts into English "as a way to make the primary storylines in the text more accessible" (Woldeyes 2019, p. 9). Spending time in the churches was an important part of Yirga's education. Even before he was able to read, the artwork that was displayed throughout the churches told stories of connecting the Tewahido Church back to the Middle East. As he grew up, he heard the story of how when King Lalibela was born, he was swarmed by bees, which was seen as an omen for miraculous deeds to come, and watched as people came to Bete Giyorgis (St. George) to receive holy honey that dates back to Lalibela's time in 900 CE.

I would like to pause for a minute on the bees. Studies have shown they have complex skills in communication that are connected to advanced physics. In a chapter of Spaces of Hope David Harvey calls "The Insurgent Architect," he writes: 
The intricacy and complexity of the communication system (and the accuracy and precision incorporated into it) demonstrates a truly amazing capacity for bees to encode and communicate information in the abstract, symbolic way that would shame many a communications or GIS specialist ... The entire repertory of bee dances with all of its innumerable parts and variations falls within a mathematical schema unknown to any architect. The only other known physical process to which such mathematics applies concerns quarks in quantum theory ... If [bees somehow have this knowledge] then bees "know" (with a tiny brain) a kind of mathematics known to only a handful of people, but they may also be able to do what no human appears ever able to do-operate in quantum fields without disturbing them. (Harvey 2000, pp. 201-2)

The symbolism of bees for King Lalibela, who went on to create some of the most stunning architecture on the planet, may be explored in more depth as the relationship between bees and their environments continues to be studied.

In 1978, United Nation Educational, Scientific and Cultural Organization (UNESCO) recognized Lalibela's "contributions to humanity" by naming it a World Heritage site. Tragically, in the process of connecting the churches to a network of international sites, the relationship between the people of Lalibela and the churches was not appreciated. In Seeing Like A State: How Certain Schemes to Improve the Human Condition Have Failed, James Scott explains how "top-down" planning often misses the importance of respecting and incorporating "metis," which he defines as:

a wide array of practical skills and acquired intelligence in responding to a constantly changing natural and human environment ... The practice and experience reflected in metis is almost always local. (Scott 1998, pp. 315-17)

Since UNESCO "inscripted" the churches in Lalibela, many residents of the rock-hewn buildings, as well as the surrounding neighborhood, were forced to relocate. Yirga explains that UNESCO adopted:

new concepts such as "heritage," "property," "conservation," and "authenticity" that do not incorporate the meanings and experiences local people have had with the churches in the region. The World Heritage Committee insisted on the creation of boundaries, buffer zones, and conservation zones around "the property". (Woldeyes 2019, p. 18)

Lalibela is not the only local community that has had a difficult time reconciling with UNESCO. While it may seem as an exceptional honor to be named a treasure of the world, the impacts of conservation and the development of sites for an international tourist market are often managed outside the communities that have historic ties to the sites (Adams 2006; Collins 2008; Davis 2015).

As a part of the United Nations, which oversees the Universal Declaration of Human Rights-developed to protect individuals and nations who may be targeted for discrimination, displacement, and forced assimilation in the states where they reside-UNESCO could be a leader in developing infrastructure to support the land rights of living communities, yet often the economics of the designation interfere with supporting the living communities who are intimately connected to the sites (Kirchenblatt-Gimblett 2006; Regis 2013).

In 1992, UNESCO recognized K'gari (pronounced "Gurry" for English-speakers)/Fraser Island, off the southern coast of Queensland, as a World Heritage site. See Figure 13. In their online database, the island's exceptional ecology as the largest sand island in the world is discussed:

Majestic remnants of tall rainforest growing on sand and half the world's perched freshwater dune lakes are found inland from the beach. The combination of shifting sand-dunes, tropical rainforests and lakes makes it an exceptional site (UNESCO). 


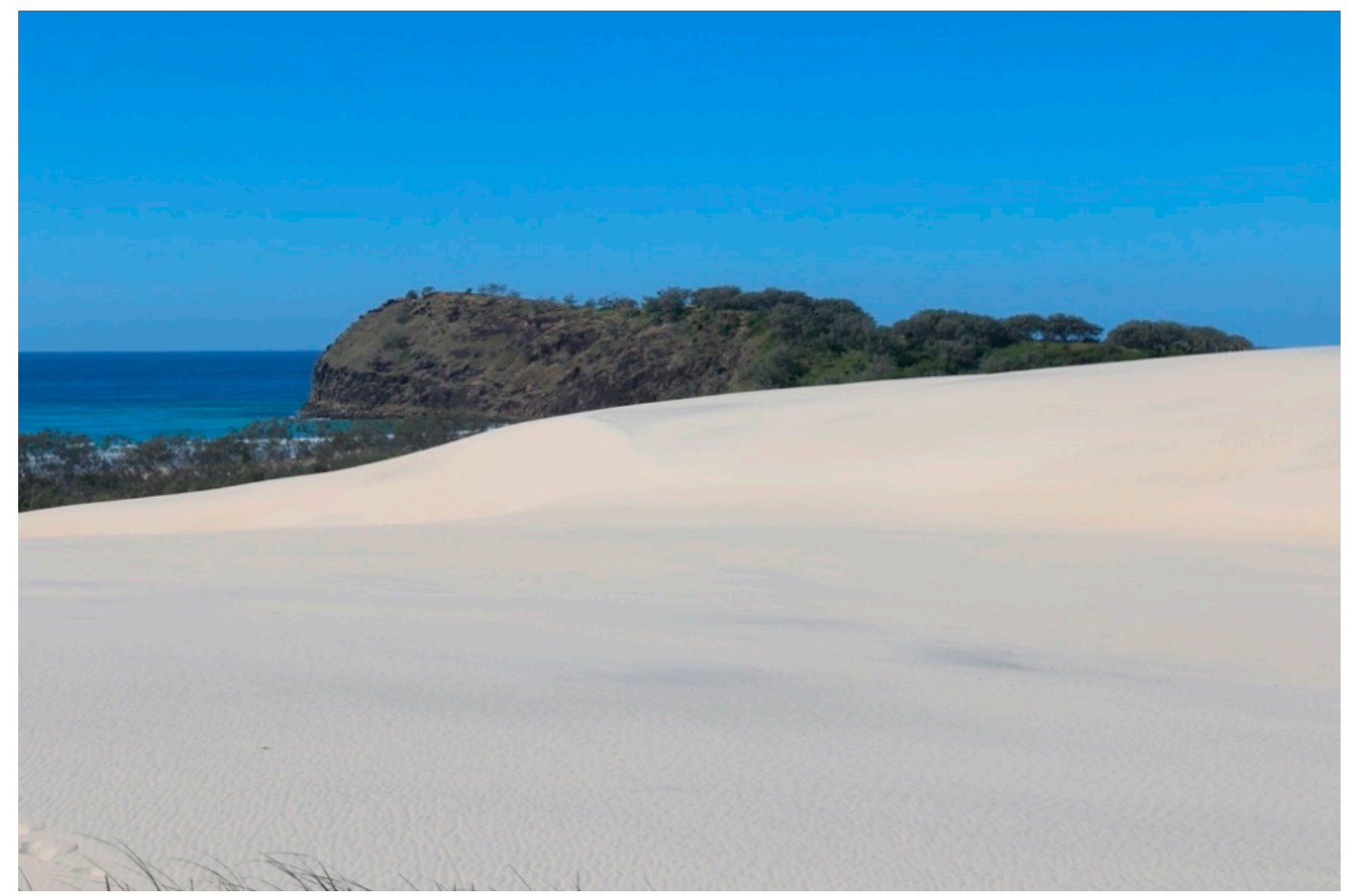

Figure 13. One of the sand dunes on K'gari (Fraser Island) overlooking Takky Wooroo (Indian Head). Photograph by Fiona Foley.

The description emphasizes the natural beauty of the island without acknowledging the traditional owners of the land, the Badtjala Nation. The UNESCO inscription occurred the same year that Australia's legal argument that the former British colony was founded on terra nullius (a land belonging to no one) was overthrown in the High Court's decision in Eddie Mabo v. the State of Queensland. The following year, in 1993, the Labour government passed the Native Title Act, which legislated how Aboriginal land rights would be recognized. The framework excluded Nations who were most directly impacted by policies of forced assimilation:

The High Court held that "when the tide of history has washed away any real acknowledgment of traditional law and any real observance of traditional customs," the foundation of native title disappeared and native title rights were extinguished. As if merely substituting the notion of culture for an older version of race, the court argued that if Aboriginal culture interbred with another "heritage" to some undefined degree, it forfeited these rights. (Povinelli 2002, p. 164)

For generations, the Wondunna clan of the Badtjala Nation has countered this argument with their cultural activism, writing, and art. Following in her family's lineage, artist and scholar Fiona Foley has created a stunning body of work dedicated to K'Gari. See Figure 14. In a review of her artwork in our special issue, "Source to Subject: Fiona Foley's Evolving Use of Archives," art historian Marina Tyquiengco explains, "Over the years, her practice of engaging the archive to connect with the genealogy of the Badtjala has expanded to include the artist as a subject, witness, and/or participant" (Tyquiengco 2020). In her own article in this special issue, "The People of K'Gari/Fraser Island: Surviving 250 Years of Racial Double-Coding," Fiona weaves together her family's genealogy with the history of the island, including the cultural activism of her mother, Shirley Foley, who was central to the Badtjala's Native Title Claim (Foley 2020). 


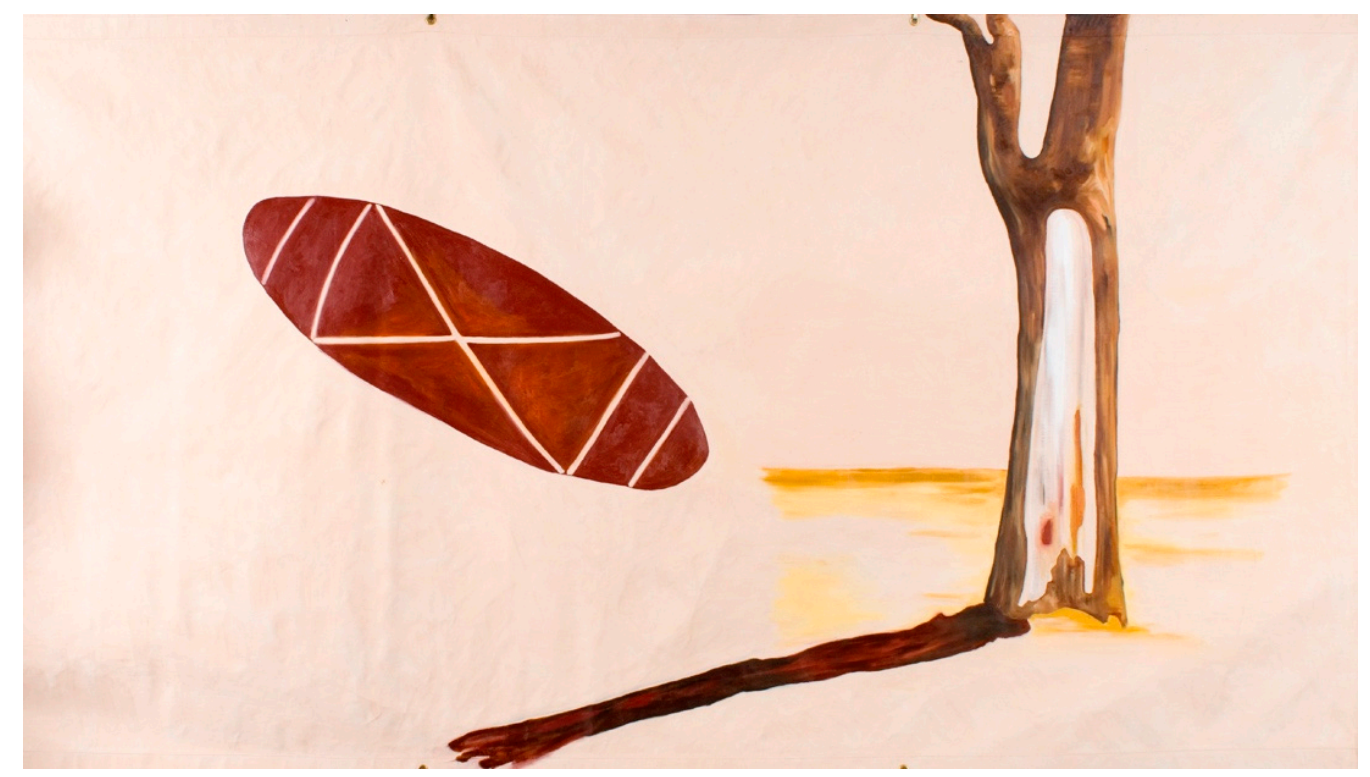

Figure 14. Fiona Foley Scar Tree (2000). Oil on Canvas. Showing the trunk of a tree in southern Queensland that has a scar from where bark was taken to build a shield, Foley protests the Hervey Bay City Council's decision to tear down a tree that was a living example of the Badtjala Nation's connection to their land.

In an interview in The Sydney Morning Herald, she shares the impact of the UNESCO inscription on K'gari: "It is disconcerting because basically the island is over-loved now. There are too many people and it takes its toll on the environment there." The Herald goes on to explain:

Although the Badtjala people won their Native Title claim, Foley says they gained very few actual rights and can't make money from the tourism. It's a point of ongoing frustration for Foley, who has argued for a levy to be imposed on all vehicle permits for the island, the funds of which could be reinvested in Badtjala cultural programs. (Kembrey 2020)

Of particular concern for Fiona is the preservation of the Badtjala language. She edited and republished her mother's book, Badtjala-English, English-Badtjala Word List. In this special issue, we also have the opportunity to watch a short film she directed on K'gari, Out of the Sea like Cloud. With the help of her mother's dictionary and singer/songwriter Telia Watson, the film repatriates a Badtjala song back into their language. As Fiona writes in her article, "Our language had been sleeping for many years and was awoken. It was the first time the full weight of my mother's work had been activated in such a space" (Foley 2020).

Building on the importance of holding onto ties between language, kinship, and place, Helene Connor's article in this special issue, "Whakapapa Back: Mixed Indigenous Maori and Pakeha Genealogy and Heritage in Aotearoa/New Zealand," is centered on the lived experiences of Maori genealogy. Growing up, her grandmother, Lulu Coulter Skelton, taught her how to recite her paphea (the formal way for a person of Maori descent to introduce themselves) to understand and share her connections to their land and tribe. Lulu Skelton raised her children near their mountain, Taranaki, speaking Maori, and incorporating the intimacy she felt with the land into Western holidays. Helene writes:

Christmas time was usually shared with extended whanau and neighbours. She prepared a gigantic Christmas family picnic. The children loaded the truck up and they trekked off to some outlying place- - the bush or the lake—and dragged all the gear up there to enjoy lunch. When the parents fell asleep, the children ran riot in the bush to explore new territory. (Connor 2019, p. 10) 
Her grandmother's marae was at Manukorihi, ("chorus of birds" in English), an ancient pa located in northern Taranaki above the Waitara river. Famed for never being taken by another taua (invading party), the Te Ati Awa tribe commissioned a new meeting house, Te Ikaroa a Maui, with elaborate whakairo (carvings), kohaiwhari (painted carvings), and tukutuku (weavings). They debuted it with a public ceremony in 1936 when Helene's grandmother was in her early 20s: See Figure 15.

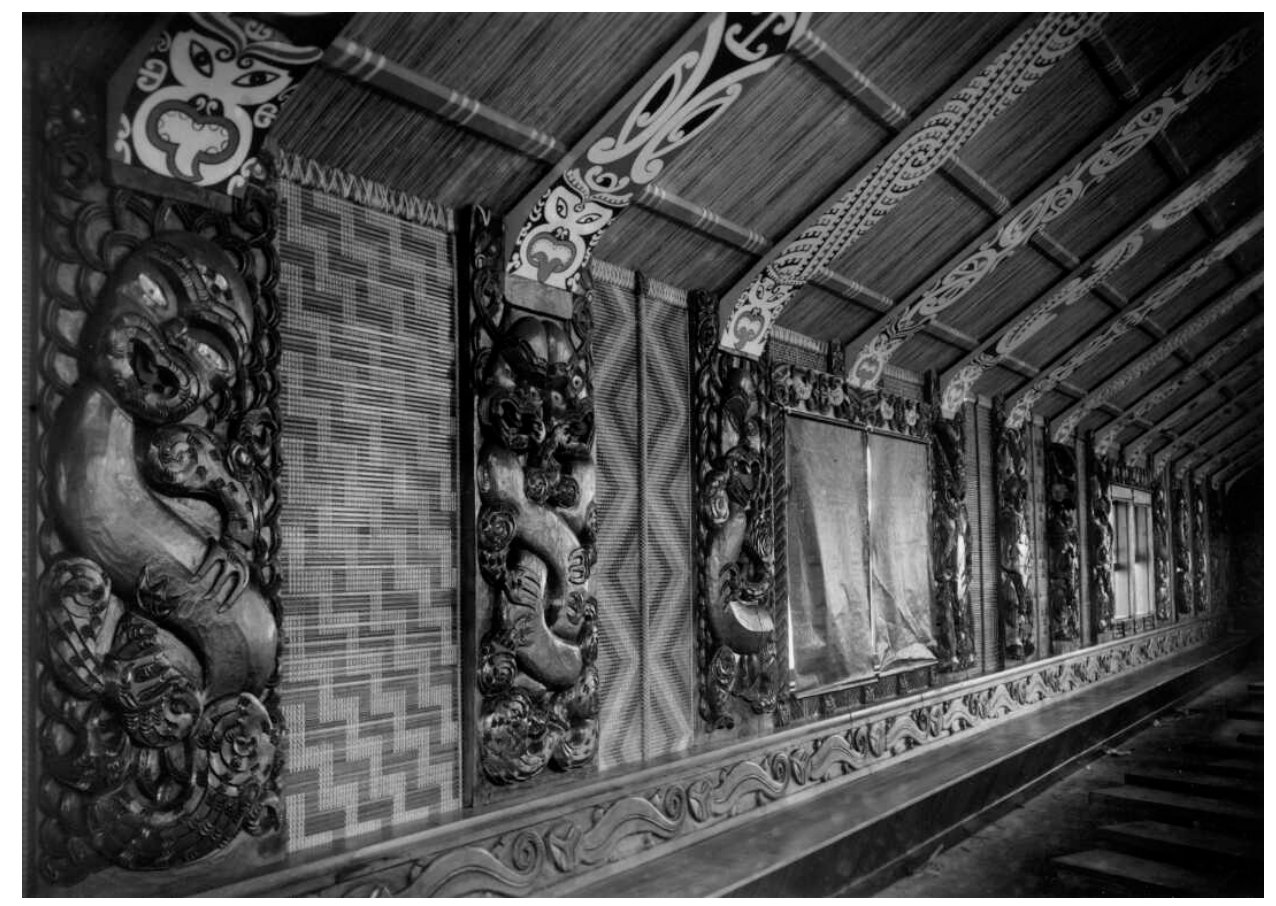

Figure 15. Carvings and weavings inside Helene Connor's marae, Te Ikaroa a Maui, Owae Marae, Manukorihi Pa, Waitara. Photograph by John Houston (1891-1962). Papers Reference $\frac{1}{2}$ x-025177-F. Alexander Turnbull Library, Wellington, New Zealand.

Like Yirga and Fiona, Helene grew up visiting a place where her genealogy was not just explained, but part of the landscape and embedded in the art, architecture, and scholarship of her family. It was here that she attended many ceremonies honoring people in her tribe. Now a senior lecturer of Maori education and social work at the University of Auckland, Helene has worked for years to teach best practices of culturally relevant mental health care for people of Maori descent. Sharing best practices that have emerged from her department, Helene writes that finding strategies to overcome cultural displacement, such as reconnecting to one's whakapapa, are important models for healing.

\section{Reclamations}

The models developed at the University of Auckland offer important resources to support people who have been cut off from their heritage due to forced assimilation. In Kayang and Me, Kim Scott writes about his cultural displacement in Western Australia due to generations of state policies that enforced segregated housing, education, and job opportunities:

I didn't grow up in the bush. There was no traditional upbringing of stories around the camp fire, no earnest transmission of cultural values. The floor of the first house I remember was only partially completed, and my three siblings and I, pretending we were tightrope walkers, balanced on the floor-joints spanning the soft dirt and rubble half a metre below us.

We moved to a government house on a bitumen street with gutters running down each side, and even though the street came to an end, the slope ran on and one through patchy scrub and past the superphosphate factory, the rubbish tip, the Native Reserve. 
Individuals were fined for being on the reserve and fined for being in town. Their crime was being non-Aboriginal in the one place and Aboriginal in the other, after legislation was refined in the attempt to snare those who-as the frustrated bureaucrat put it_-"run with the hares and hunt with the hounds" and to trip them as they moved to and fro across a dividing line.

My father was mobile that way, always moving (Scott and Brown 2005, p. 14)

Kim Scott's father died in his 30s. His son said that he was not able to articulate the impact of his own experiences of colonization, but Judy Atkinson's work in Trauma Trails: Recreating Song Lines, may be able to describe some of his experiences with collective trauma:

It seeps slowly and insidiously into the fabric and soul of relationship and beliefs of people as community. The shock of loss of self and community comes gradually. People, feeling bereaved, grieve for their loss of cultural surrounds, as well as for family and friends. Feeling victimised, the same people may also carry a deep rage at what has happened to them, but may be unable to express their anger at those they perceive to have violated their world and caused the death of their loved ones (Atkinson 2002)

Through his commitment to understanding his family history, and learning the Noongar language, Scott has been able to reconnect to parts of his heritage that were severed. Around the world, artists, scholars, and community-based activists are reclaiming indigenous knowledges through acts of creation. The photography of Greg Semu provides one example. I first saw his work at the Queensland Museum of Art in Brisbane, Australia, in 2010. As part of UNNERVED: The New Zealand Project, he exhibited self-portraits that showed the different sides of his pe'a, the traditional men's body tatau of Samoa. In Samoan, the verb tā means to strike, and in the case of tatau, refers to the "tap" sound of the comb used to penetrate the skin with ink. The verb tau translates as "to reach an end," but also means war or battle. Put together, tatau also translates as "rightness" or "balance." See Figure 16.

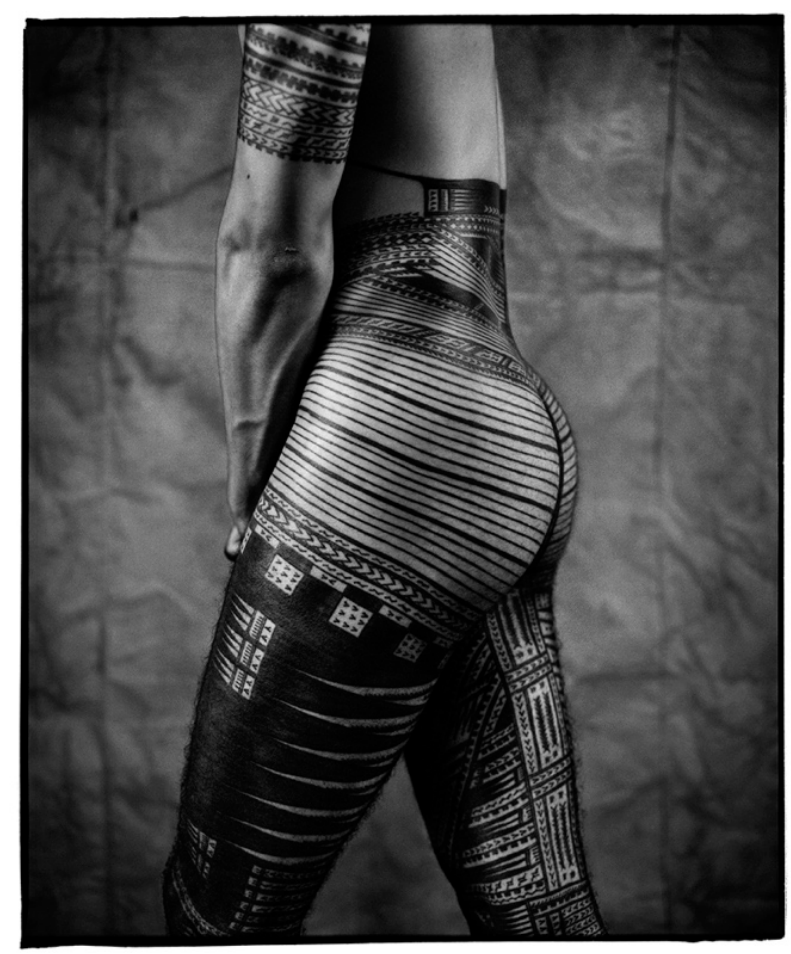

Figure 16. Self-portrait by Greg Semu of his $p e^{\prime} a$, the traditional men's tatau from Samoa. Image courtesy of the artist. 
In his exhibit, Greg presented self-portraits of the exacting, elegant lines of the tatau against a wrinkled backdrop set up in a studio. Before colonization, men in Samoa who weren't tattooed were called telefua-naked. To go through the long process was a sign of bravery. For Greg, the process was a way of reconnecting to parts of Samoan culture that had been cut off from him growing up in Auckland, New Zealand, in the 1970s. Greg's parents were opposed to tattooing because of their Mormon faith and focused on fitting into white/pakeha society. Although fluent in Samoan, they spoke to him in English. In Auckland, Greg's generation was caught in the animosity that had grown between Maori and other Pacific Islanders and turned to street photography to begin to read the complexity of the urban landscape. In his early 20s, he was introduced by one of his photography mentors to a tufuga ta tatau (tatau master) who descended from one of the two families in Samoa that have passed on the tradition for generations and decided to go through the painful process. The traditional pe'a on his body provided a "passport" that connected him to other Samoan men in diaspora. In subsequent years, he has worked with Indigenous communities around the South Pacific to reimagine their histories.

In Australia, artist Eric Bridgeman began his career creating a series of artwork that confronted the country's stereotypes of people from Papua New Guinea. In staged portraits, he turned the lens of the white gaze back on the viewer. Over time, however, he realized that focusing on this way of looking limited him and his relationship to his mother's family in Papua New Guinea. As Toni Morrison has written, “The very serious function of racism ... is distraction. It keeps you from doing your work. It keeps you explaining, over and over again, your reason for being" (Morrison 2019). Instead of repeating himself, Eric decided to focus his art practice in community with his grandfather's tribe, Yuri Alaiku, of the southern Simbu district of Gumine in the highlands of Papua New Guinea. In 2015, with the support of his uncle, Joe Kuman, the co-founder of his clan association, Yuri Alaiku Kuikane Association (YAKA) and a lecturer at the University of Goroka, Eric helped found Haus Yuriyal, a collective of more than twenty members who come together to create art in a traditional round house. See Figure 17.

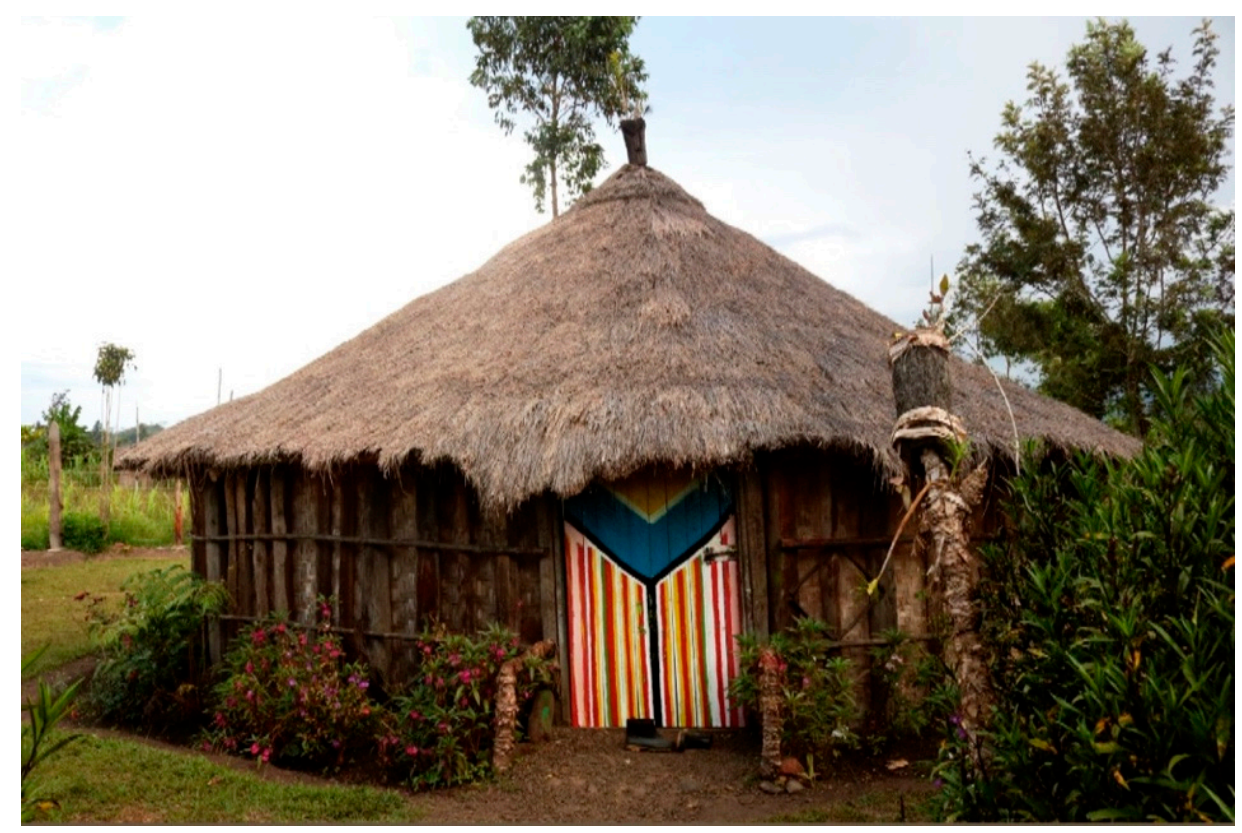

Figure 17. The round house in Wahgi Valley, Jiwaka Province, Papua New Guinea, built by Eric Bridgeman's extended Yuri family. Members of the art collective Haus Yuriyal meet to paint and bilas (to beautify) their community. Photograph by Eric Bridgeman.

In an artist statement for an exhibit he created with Haus Yuriyal, Eric writes:

Our drawings and paintings address old (tumbuna/bipo taim) ideas, woven and marked out by a new generation of men and women from our community. We have begun telling 
stories through what we have seen and what we know-shields and bilum weaving. In the Highlands we are surrounded by dramatic mountains and unique beauty, made delicate by the complexities of warfare, violence and colonial presence. We compound these sometimes challenging situations through ceremonial acts of 'bilas' (noun: costume/verb: to beautify). Our studies into our own ancestral shields has led us as a group to understand the power of its visual language; to identify the signifiers of the tribal fight, learning from conflicts of the past in order to control forms of negativity, and come to harness the positivity of our designs for protection, and for amamas [happiness]. (Bridgeman 2020)

Haus Yuriyal is an example of the importance of creating "community-based grassroots structures [that] hold our memories sacred" (Dizon and Lê 2018). Haus Yuriyal's success in Australia is just one example of how, with a solid foundation, cross-cultural ties can be forged that develop long-lasting friendships, respectful dialogue, and economic opportunity across place. See Figure 18.

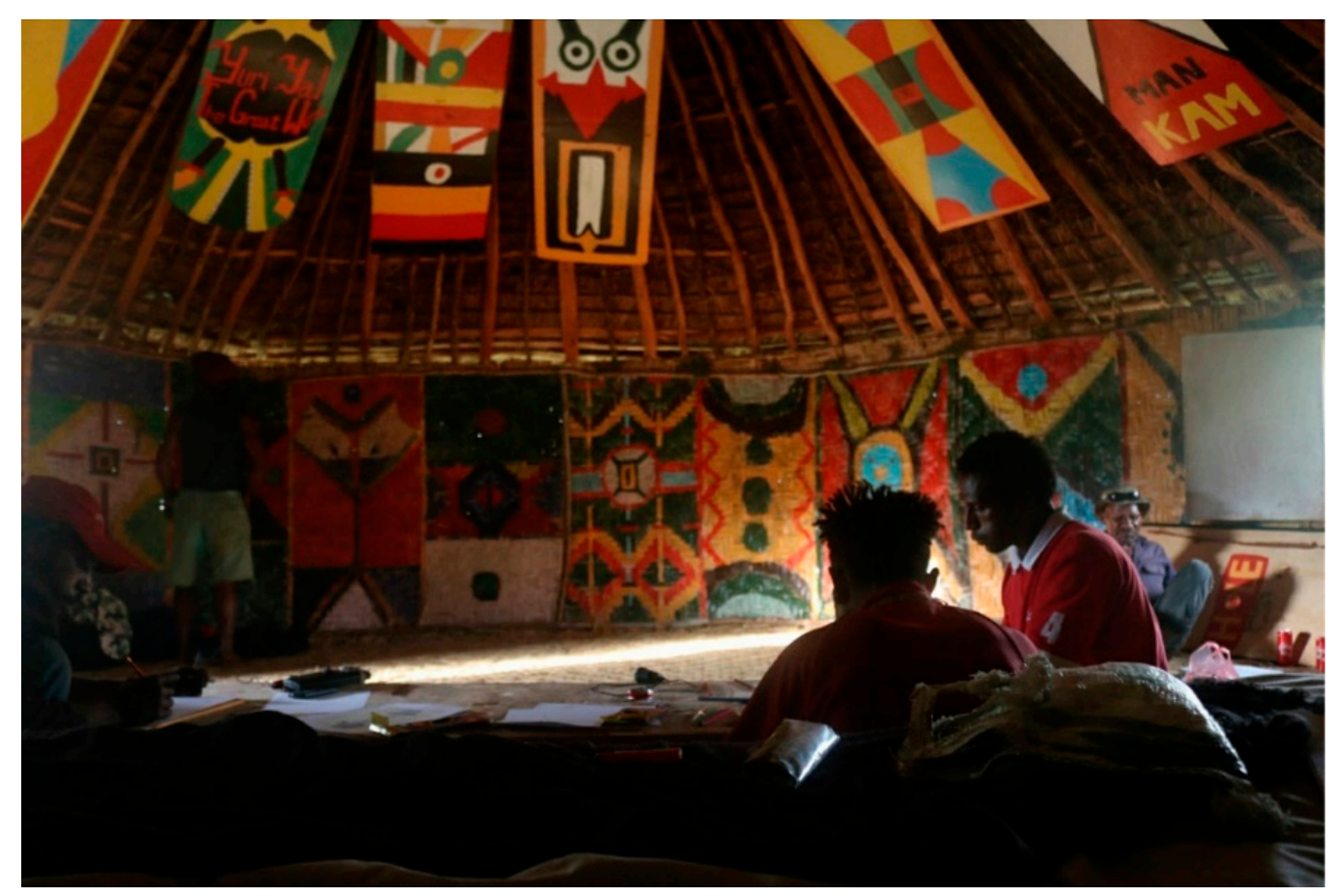

Figure 18. Members of the art collective Haus Yuriyal work on paintings based on the art form of ancestral shields in their round house in the Wahgi Valley of Papua New Guinea. Photograph by Eric Bridgeman.

In 2020, the Neighborhood Story Project published Return to Yakni Chitto: Houma Migrations, a book of black and white photography and that traces the genealogy of the Houma Nation, and their forced and voluntary migrations over hundreds of years (Verdin 2019). The author, Monique Verdin, wrote about her father's fierce pride in his heritage but also his embrace of multiracial, cross-cultural friendships that also supported him throughout his life. See Figure 19. 


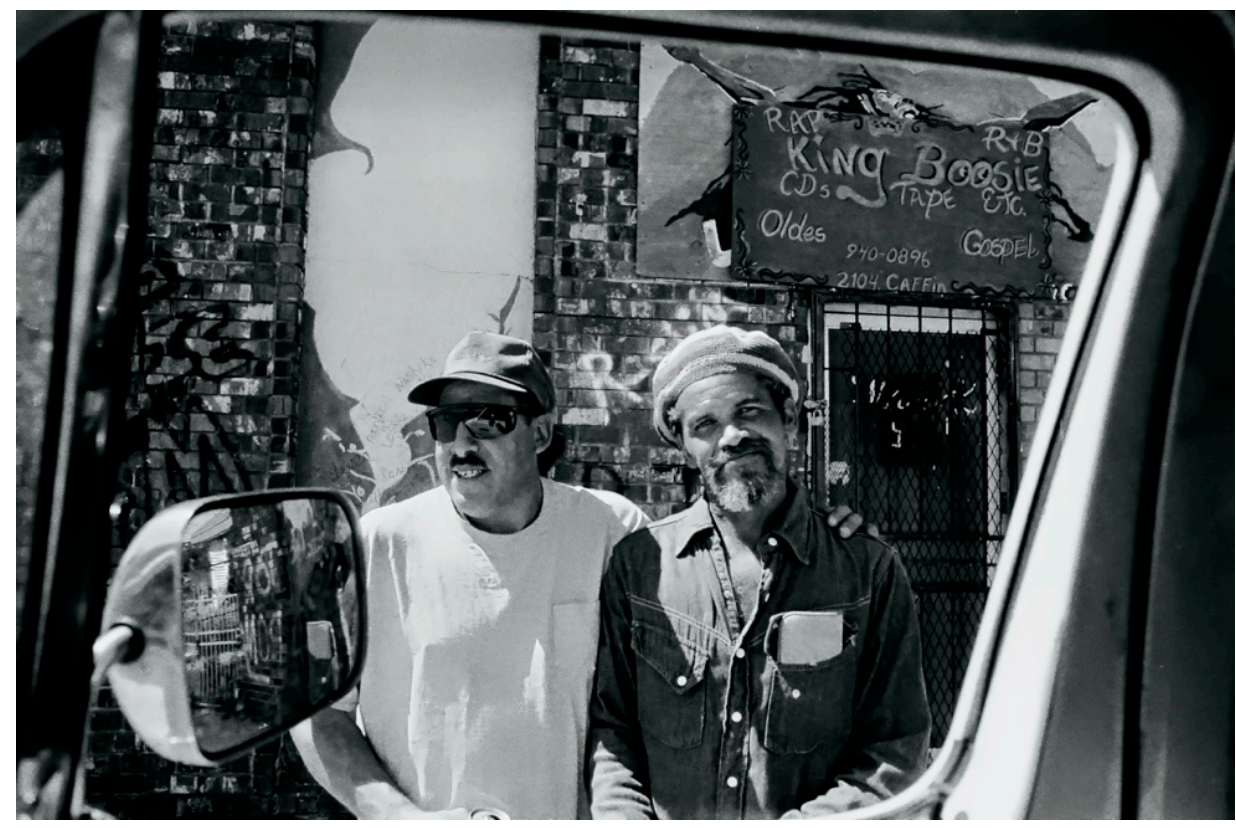

Figure 19. Monique Verdin's father, Michelle Verdin, with his friend John Taylor in the Lower Ninth Ward of New Orleans in the late 1990s. Photograph by Monique Verdin.

Growing up, she visited Lower Ninth Ward of New Orleans to meet up with his friends. Monique writes:

In our shortcuts through back-a-town, he introduced me to his friend, John Taylor. John told me, "Everybody called your dad Julio, but I knew he wasn't Mexican. I knew he was from the Parish. I was going into the Bayou Bienvenue swamp and bringing out garfish, and your dad was always up from down the road selling shrimp, coons, or turtle to all the Creoles who lived in the Lower Ninth Ward." Both my dad and John were wild salesman who could see the truth. If you passed them in the street, maybe you wouldn't think twice, but they recognized real, simple beauty from the freedom they found in that wildness. (Verdin 2019, p. 33)

When we published Return to Yakni Chitto, Monique said that she wanted to honor her father's love of their family's traditions and his appreciation of other cultures by putting it into practice. As we talked about what the events could look like, we drew inspiration from a passage that she wrote about an afternoon in the mid-1980s when her father took her to their relatives, Jane and Anesie Verdin's home in Pointe-aux-Chenes:

[W] came up to a bunch of people gathered around a pile of freshly boiled shrimp on top of a makeshift plywood and sawhorse table, talking in Houma French. That memory stayed with me through my childhood. It was unlike other parts of the U.S. I had known. It felt like home. (Verdin 2019, p. 30)

In the Unbearable Lightness of Being, Milan Kundera writes, "The brain appears to possess a special area which we might call poetic memory and which records everything that charms or touches us, that makes our lives beautiful" (Kundera 1984, p. 208). Monique wanted to share this beauty that came from her extended Houma family with her community and the broader, diverse audiences we imagined for the book and companion exhibit. At the Neighborhood Story Project's workshop in an old corner store building in the Seventh Ward, we hosted the exhibit and book release that emphasized leisure as "an affirmation of humanity" (Jackson 2020, p. 77). Our neighbors shucked oysters and cooked large pots of gumbo, we played bouré-a Louisiana card game - and danced. Then Monique and I packed up the exhibit and brought it down to Los Isleños Museum, dedicated to the history of Canary Islanders, to join a cross-cultural conversation about different migrations to St. Bernard Parish. See Figure 20. 

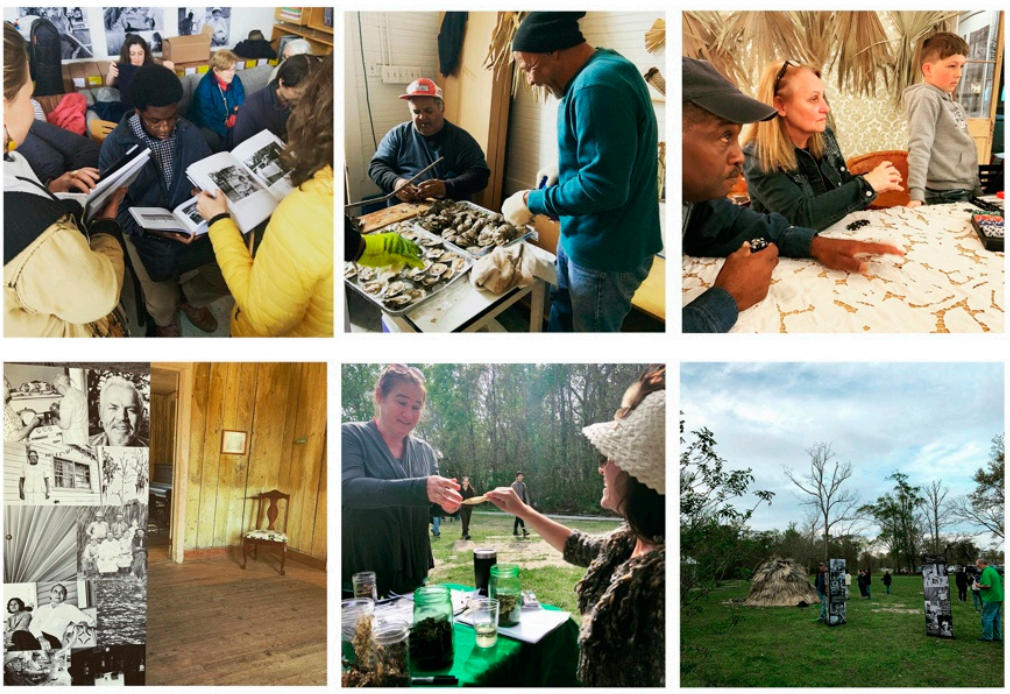
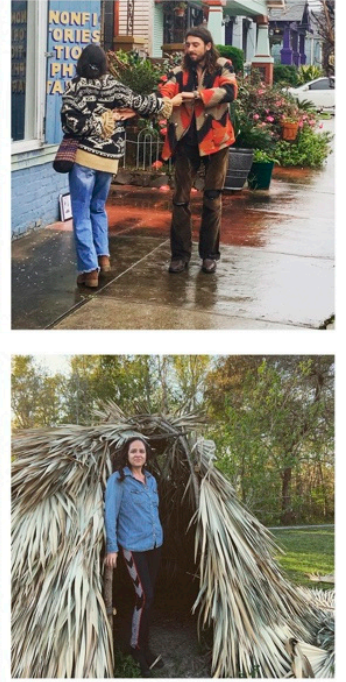

Figure 20. A collage from the exhibit and book release of Monique Verdin's book, Return to Yakni Chitto. (Top): Events at the Neighborhood Story Project's workshop. (Bottom): The exhibit, curated by artist Michel Varisco with poetry by Raymond "Moose" Jackson, at the Land Memory Bank and Seed Exchange's installation, which included the building of a traditional Houma palmetto hut, at Los Isleños Museum's annual Fiesta in St. Bernard Parish. Photographs by Rachel Breunlin, courtesy of the Neighborhood Story Project.

Monique also developed a course, "Palmetto Weaving and Indigenous Knowledges," at the Neighborhood Story Project's workshop where she co-taught with other Indigenous scholars and activists. She harvested palmetto fronds from her family's land in St. Bernard Parish and brought them to the office to dry. We asked my neighbors for buckets of water where we then soaked strips of the plants that would be used by the class. When people came to visit the workshop, they commented on the comforting smell of the palmetto-bringing them back to their childhoods when they didn't think twice about lying on the ground of a forest and breathing in the cycles of birth and death around them. Two weeks into the course, Monique and I talked about how the teaching was going and she said the class allowed her to hold a space where everyone's histories and experiences were welcomed. Through the act of weaving, they participated in a shared activity that also tied their stories together.

The course didn't require any special skills-the idea was to get started and be guided in the process. It is the same way we create books. I learned the method when I read Ngugi wa Thiongo's Decolonizing the Mind: The Politics of Language in African Literature. This small book, shared by one of my African diaspora professors, Guarav Desai, in my last semester of college, had a profound impact on me. One of the central arguments of the book is that practicing in secret weakens our social fabric, as people see performances, art, and writing only in their final stages where they believe, "[O]h, it must take such brains!" (wa Thiongo 1997, p. 56). In his own theatre productions, Ngugi advocated opening up rehearsals as a process of "demystifying knowledge and hence reality" (wa Thiongo 1997, p. 56). The Neighborhood Story Project's corner store building has provided a space for writing and creating books and art in the public eye. Working on a special issue that draws people together from around the world creates a gathering space as well. Borrowing the words of Denise Frazier, we "hope to spark the interest of every other person who has felt just out of reach of their sense of home and history" (Frazier 2020, p. 3).

As we have worked on editing the special issue, many spaces like churches, beaches, maraes, round houses, and corner store workshops have had to close because of the coronavirus pandemic. Travel has become limited. Around the world, our elders are dying, and borders have closed. Many of the communities that have been impacted the most by colonialism and structural racism are now the most vulnerable. On 20 March 2020, Ronald W. Lewis passed away from the virus; the future of his museum, a site for decolonizing genealogies, remains uncertain. As people are experiencing all over 
the world, the grief of losing a loved one is compounded by not being able to properly tend to our dead (Kurutz 2020). In our special issue, poet and artist Shin Yu Pai contributes an essay and film, “Embarkation: Reimagining a Taoist Ritual Ceremony," where she shares how she created a performance that incorporated poetry and film to heal from personal loss (Pai 2020). See Figure 21.

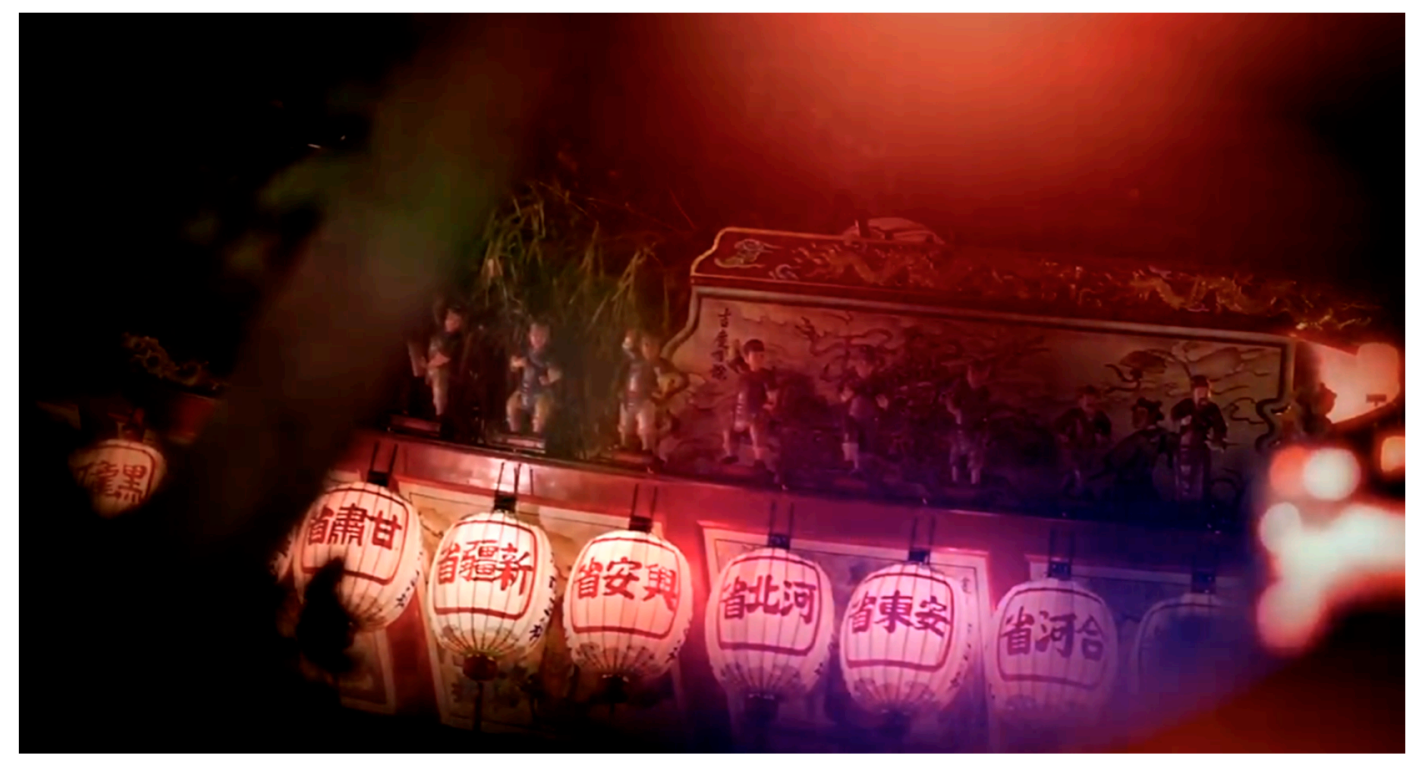

Figure 21. A still-image of film footage from the Wang Yeh boat burning festival in Donggang, Taiwan, by Ye Mimi, which the poet and artist Shin Yu Pai incorporated into her grief ritual. Image courtesy of Ye Mimi and Shin Yu Pai.

In her act of creation, she may inspire others who are grappling with personal and collective grief. In the next few months, we will continue to develop our special issue and present other articles that will contribute to the ethics of decolonization as we honor the dead. We welcome dialogue. As our editor-in-chief, Sherry Rankins Robertson, writes to us, "In solidarity of global health.".

Funding: This research received no external funding.

Acknowledgments: I would like to thank my co-editor, Antoinette Jackson, for inviting me work on this project with her, and all of our contributors for their incredible scholarship, creativity, and time commitments to our special issue. Thank you to editor-in-chief, Sherry Rankins Robertson, for believing in the multimedia format, and to managing editor Allie Shi for helping us bring the articles to publication. Thank you to Helen A. Regis, Monique Verdin and Bruce Sunpie Barnes for communing with the dead with me, to Nikki Thanos and Leo Gorman for co-parenting during our coronavirus shutdown so I could write, to Houma historian and philosopher and Michael Dardar and Atakapa-Ishak historian and publisher Jeffery Daresnbourg for reading drafts, and to Biddy Morris, Carlene Wise, and James Pillsbury for your support from Derby, Western Australia. Thank you to my parents, Douglas Breunlin and Cynthia Hart Breunlin, for raising me with a knowledge of the importance of transgenerational sequences, and to my son, Max Omar Etheridge, for joining me in so much of my work. And finally, I want to acknowledge three important people in the Neighborhood Story Project community who transitioned to the ancestral realm while working on this project: Ronald W. Lewis, Kim "Cutie" Boutte, and Sylvester Francis, Sr. Our work isn't done.

Conflicts of Interest: The author declares no conflict of interest.

\section{References}

Abu Lughod, Lila. 1993. Writing Women's Worlds: Bedouin Stories. Berkeley: University of California Press.

Adams, Kathleen M. 2006. Art as Politics: Recrafting Identities, Tourism, and Power in Tana Toraja, Indonesia. Honolulu: University of Hawaii Press.

Ahmed, Sara. 2004. The Cultural Politics of Emotion. New York: Routledge.

Atkinson, Judy. 2002. Trauma Trails: Reconnecting Song Lines. Melbourne: Spinifex. 
Barnes, Bruce Sunpie, and Rachel Breunlin. 2019. Le Kèr Creole: Creole Compositions and Stories from Louisiana. New Orleans: University of New Orleans Press.

Benjamin, Walter. 1969. The Task of the Translator in Illuminations. New York: Schocken Books.

Bird Rose, Deborah. 2004. Reports from a Wild Country: Ethics of Decolonisation. Sydney: University of New South Wales Press.

Breunlin, Rachel, and Maya Haviland, eds. 2008. Singing Out: Aboriginal Ladies' Stories from the Northwest Kimberley. The Neighborhood Story Project, and Side by Side Community Projects. Derby: Jalaris Aboriginal Corporation.

Breunlin, Rachel, and Ronald W. Lewis. 2009. The House of Dance E Feathers: A Museum by Ronald W. Lewis. The Neighborhood Story Project. New Orleans: The University of New Orleans Press.

Breunlin, Douglas, Richard Schwartz, and Betty Kune-Karrer. 2001. Metaframeworks: Transcending the Models of Family Therapy. San Francisco: Jossey-Bass Publishers.

Bridgeman, Eric. 2020. Eric Bridgeman and Haus Yuriyal: Nene Iken Ain Ere Kole Napin/We Should Go Home. Brisbane, Australia: Milani Gallery.

Carney, Judith. 2001. Black Rice: The African Origins in the Rice Cultivation of the Americas. Cambridge: Harvard University Press.

Coates, Ta-Nehesi. 2013. Trayvon Martin and the Irony of American Justice. The Atlantic Monthly. July 15. Available online: https://www.theatlantic.com/national/archive/2013/07/trayvon-martin-and-the-irony-ofamerican-justice/277782/ (accessed on 1 August 2020).

Collins, John. 2008. 'BUT WHAT IF I SHOULD NEED TO DEFECATE IN YOUR NEIGHBORHOOD, MADAME?' Empire, Redemption, and the 'Tradition of the Oppressed' in a Brazilian World Heritage Site. Cultural Anthropology 23: 279-328. [CrossRef]

Connor, Helene. 2019. Whakapapa Back: Mixed Indigenous Maori and Pakeha Heritage and Identity in Aotearoa/New Zealand. Genealogy 3: 73. [CrossRef]

Cross, Hannah. 2019. Bad luck comes, when you bulldoze boabs. National Indigenous Times. June 25. Available online: https://nit.com.au/bad-luck-comes-when-you-bulldoze-boabs/ (accessed on 26 May 2020).

Darensbourg, Jeffery. 2018. Bulbancha is Still A Place: Decolonizing the Tricentennial of New Orleans. In Bulbancha Is Still A Place: Indigenous Culture from New Orleans. Bulbancha: POC Zine Project.

Davis, Marion. 2015. Managing a Living Cultural Landscape: Lessons and Insights from the Subaks of Bali, a UNESCO World Heritage Site. Stockholm Environmental Institute. Available online: https://www.jstor.org/ stable/resrep00442 (accessed on 2 September 2020).

Davis, Dána-Ain, and Christa Craven. 2016. Feminist Anthropology: Thinking Through Methodologies, Challenges, and Possibilities. London: Rowman and Littlefield.

Dent, Tom. 2000. Secret messages. In Literary New Orleans. Edited by Judy Long. Athens: Hill Street Press.

Dizon, Michelle, and Viêt Lê. 2018. White Gaze. Chicago: CANDOR, Memory and Resistance Laboratory, and Sming Sming Books.

DuBois, William Edward Burghardt. 2014. The Soul of Black Folks. Introduction by Vann Newkirk, II. New York: Restless Classics.

Fámúlẹ̀, Oláwọlé. 2018. Èdè Àyàn: The Language of Àyàn in Yòrùbá Art and Ritual of Egúngún. Yoruba Studies Review 2. Available online: https://news.clas.ufl.edu/ede-yan-the-language-of-yan-in-yoruba-art-and-ritualof-egungun/ (accessed on 2 September 2020).

Fields, Edda L. 2008. Deep Roots: Rice Farmers in West Africa and the African Diaspora. Bloomington: Indiana University Press.

Foley, Fiona. 2020. The People of K'Gari/Fraser Island: Working Through 250 Years of Racial Double Coding. Genealogy 4: 74. [CrossRef]

Frazier, Denise. 2020. The Nickel: A History of African-Descended People in Houston, Texas. Genealogy 4: 33. [CrossRef]

Hall, Gwendolyn Midlo. 1992. Africans in Colonial Louisiana: The Development of Afro-Creole Culturel. In The Eighteenth Century. Baton Rouge: Louisiana State University Press.

Harrison, Faye, ed. 1991. Decolonizing Anthropology: Moving Further Towards and Anthropology for Liberation. Arlington: American Anthropological Association.

Hartman, Saidiya. 2008. Venus in Two Acts. Small Axe 12: 1-14. [CrossRef]

Harvey, David. 2000. Spaces of Hope. Berkeley: University of California Press. 
Haviland, Maya. 2014. The Challenge of Cross-Cultural Creativity. In Double Desire: Transculturation and Indigenous Contemporary Art. Edited by Ian McLean. Cambridge: Cambridge Scholars Publishing, pp. 117-35.

Haviland, Maya. 2017. Side by Side? Community Art and the Challenge of Co-Creativity. New York: Routledge.

Jackson, Michael. 1995. At Home in the World. Durham: Duke University Press.

Jackson, Antoinette. 2011. Shattering Slave Life Portrayals-Uncovering Subjugated Knowledge in US Plantation Sites in South Carolina and Florida. American Anthropologist 113: 448-62. [CrossRef]

Jackson, Antoinette. 2012. Speaking for the Enslaved: Heritage Interpretation at Antebellum Plantation Sites. New York: Left Coast Press.

Jackson, Antoinette. 2020. Heritage, Tourism, and Race: The Other Side of Leisure. New York: Routledge.

Kebede, Messay. 2003. Eurocentrism and Ethiopian Historiography: Deconstructing Semitization. International Journal of Ethiopian Studies 1: 1-19.

Kembrey, Melanie. 2020. Artist Fiona Foley explores how opium was used to control Aboriginal labor. The Sydney Morning Herald. January 3. Available online: https://www.smh.com.au/culture/art-and-design/artistfiona-foley-explores-how-opium-was-used-to-control-aboriginal-labour-20191230-p53niv.html (accessed on 2 May 2020).

Kimmerer, Robin Wall. 2013. Braiding Sweetgrass: Indigenous Wisdom, Scientific Knowledge, and the Teachings of Plants. Minneapolis, Minnesota: Milkweed Editions.

Kirchenblatt-Gimblett, Barbara. 2006. World Heritage and Cultural Economics. In Museum Frictions: Public Culture/Global Transformations. Edited by Ivan Karp, Corinne A. Kratz, Lynn Szwaja and Tomas Ybarra-Frausto. Durham: Duke University Press, pp. 161-202.

Kundera, Milan. 1984. The Unbearable Lightness of Being. New York: Harper's \& Row.

Kurutz, Steven. 2020. Ronald W. Lewis, Preserver of New Orleans Black Culture, Dies at 68. The New York Times. April 9. Available online: https://www.nytimes.com/2020/04/09/us/ronald-w-lewis-dead-coronavirus.html (accessed on 11 April 2020).

McGregor, William B. 2006. Prolegomenon to a Warrwa grammar of space. In Grammars of Space: Explorations in Cognitive Diversity. Edited by Stephen C. Levinson and David P. Wilkins. Cambridge: Cambridge University Press.

McGregor, William B. 1994. Warrwa. Munich: Languages of the World/LINCOM.

Morrison, Toni. 1987. Beloved. New York: Plume, a Division of Penguin Books.

Morrison, Toni. 2019. 12 of Toni Morrison's Most Memorable Quotes: The authors thoughts on writing, freedom, identity, and more. The New York Times. August 6. Available online: https://www.nytimes.com/2019/08/06/ books/toni-morrison-quotes.html (accessed on 10 August 2020).

Mydans, Seth. 2007. Across Cultures, English is the Word. In The New York Times. April 9. Available online: https://www.mdpi.com/2313-5778/4/3/92 (accessed on 1 September 2020).

One Arm Point Remote Community School. 2010. Our World; Bardi Jaawi Life at Ardiyooloon. Broom: Magabala Books.

Pai, Shin Yu. 2020. Embarkation: Reimagining a Taoist Ritual Ceremony. Genealogy 4: 92. [CrossRef]

Poelina, Anne. 2013. Our Nyikina Story: Australian Indigenous People of the Mardoowarra. Cultural Survival Quarterly. Available online: https://www.culturalsurvival.org/publications/cultural-survival-quarterly/ournyikina-story-australian-indigenous-people-mardoowarra (accessed on 24 May 2020).

Poelina, Anne. 2016. Blood Line, Song Line. Great Australian Story. August 12. Available online: https: //greataustralianstory.com.au/story/blood-line-song-line-pt2 (accessed on 24 May 2020).

Poelina, Anne. 2018. Mardoowarra-Fitzroy River. Water Justice Hub. Available online: https://waterjusticehub. org/mardoowarra-fitzroy-river/ (accessed on 6 August 2020).

Povinelli, Elizabeth A. 2002. The Cunning of Recognition: Indigenous Alterities and the Making of Australian Multiculturalism. Durham: Duke University Press.

Rasmussen, Daniel. 2017. New Orleans Forgotten Slave Revolt. The Daily Beast. July 13. Available online: https://www.thedailybeast.com/new-orleans-forgotten-slave-revolt-by-dan-rasmussenamerican-uprising-author (accessed on 10 August 2020).

Regis, Helen A. 2019. Local, Native, Creole, Black: Claiming Belonging, Producing Autochthony in New Orleans. In Remaking New Orleans: Beyond Exceptionalism and Authenticity. Edited by Thomas Adams and Matt Sakakeeny. Durham: Duke University Press, pp. 138-61. 
Regis, Helen A. 2013. Producing Africa at the New Orleans Jazz and Heritage Festival. African Arts 46: 70-85. [CrossRef]

Regis, Helen A, Rachel Breunlin, and Ronald W. Lewis. 2011. Building Collaborative Partnerships Through a Lower Ninth Ward Museum. Practicing Anthropology 33: 4-11. [CrossRef]

Rosenthal, Judy. 1998. Possession, Ecstasy, and Law in Ewe Voodoo. Charlottesville: University of Virginia Press.

Saunt, Claudio. 2020. Unworthy Republic: The Dispossession of Native Americans and the Road to Indian Country. New York: W.W. Norton \& Company.

Schwab, Gabriele. 2010. Haunting Legacies: Violent Legacies and Transgenerational Trauma. New York: Columbia University Press.

Scott, David. 1991. That Event, This Memory: Notes on the Anthropology of African Diasporas in the New World. Diasporas: A Journal of Transnational Studies 1: 216-84. [CrossRef]

Scott, James C. 1998. Seeing Like a State: How Certain Schemes to Improve the Human Condition Have Failed. New Haven: Yale University Press.

Scott, Kim, and Hazel Brown. 2005. Kayang and Me. Perth: Fremantle Arts Centre Press.

Stanner, William Edward Hanley. 1979. White Man Ain't Got No Dreaming: Essays, 1938-1973. Canberra: Australian National University Press.

Stoller, Paul. 2009. The Power of the Between: An Anthropological Odyssey. Chicago: University of Chicago Press. Tyquiengco, Marina. 2020. Subject to Source: Fiona Foley's Evolving Use of Archives. Genealogy 4: 76. [CrossRef] Ulysses, Gina Athena. 2015. Introduction to Caribbean Rasanblaj. Emisférica 12. Available online: https: //hemisphericinstitute.org/en/emisferica-121-caribbean-rasanblaj.html (accessed on 16 May 2020).

Verdin, Monique. 2019. Return to Yakni Chitto: Houma Migrations. Edited by Rachel Breunlin with an introduction by Michael Dardar and poems by Raymond Moose Jackson. New Orleans: University of New Orleans Press.

wa Thiongo, Ngugi. 1997. Decolonising the Mind: The Politics of Language in African Literature. Portsmouth: Heinmann.

Wagner, Bryan. 2019. The Life and Legend of Bras Coupé: The Fugitive Slave Who Fought the Law, Ruled the Swamp, Danced at Congo Square, Invented Jazz, and Died for Love. Baton Rouge: Louisiana State University Press.

Wegmann, Mary Ann, Louisiana State Museum, and University of New Orleans History Department. 2020. Jackson Square during the Battle of New Orleans. New Orleans Historical. Available online: https: //neworleanshistorical.org/items/show/623 (accessed on 10 August 2020).

Williams, Raymond. 1977. Marxism and Literature. Oxford: University of Oxford Press.

Woldeyes, Yirga. 2020. 'Holding Living Bodies in Graveyards': The Violence of Keeping Ethiopian Manuscripts in Western Institutions. M/C Journal. Available online: http://journal.media-culture.org.au/index.php/mcjournal/ article/view/1621 (accessed on 22 July 2020).

Woldeyes, Yirga. 2019. Lalibela: Spiritual Genealogy beyond Epistemic Violence in Ethiopia. Genealogy 3: 66. [CrossRef]

(C) 2020 by the author. Licensee MDPI, Basel, Switzerland. This article is an open access article distributed under the terms and conditions of the Creative Commons Attribution (CC BY) license (http://creativecommons.org/licenses/by/4.0/). 